Original paper

\title{
Emplacement history of the Trosky basanitic volcano (Czech Republic): paleomagnetic, rock magnetic, petrologic, and anisotropy of magnetic susceptibility evidence for lingering growth of a monogenetic volcano
}

\author{
Michael S. PETRONIS ${ }^{*}$, Adam R. BRISTER ${ }^{1}$, Vladislav RAPPRICH ${ }^{2}$, Benjamin van WYK de \\ VRIES $^{3}$, Jennifer LINDLINE ${ }^{1}$, Jan MIŠUREC ${ }^{2}$ \\ ${ }^{1}$ Environmental Geology, Natural Resources Management Department, New Mexico Highlands University, Las Vegas, NM 87701, USA; \\ mspetro@nmhu.edu \\ ${ }^{2}$ Czech Geological Survey, Klárov 3, 11821 Prague 1, Czech Republic \\ ${ }^{3}$ Laboratoire Magmas et Volcans, Université Blaise Pascal - CNRS - IRD, OPGC, 5 rue Kessler, 63038 Clermont-Ferrand, France \\ * Corresponding author
}

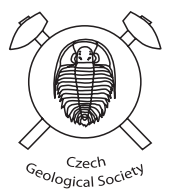

A well-preserved set of mid-Miocene scoria- and tuff-cones and their feeders crops out in the Jičín Volcanic Field, Czech Republic. The Trosky volcano is a scoria cone that has been eroded to reveal the volcano's feeder system. This edifice offers the opportunity to improve the understanding how magma is transported through a monogenetic pyroclastic cone. Physical volcanology, petrology, anisotropy of magnetic susceptibility (AMS) and paleomagnetic data were combined to study of the erosional remnant of the Trosky volcano. Selective erosion has exposed spectacular remnants of a twin scoria cone intruded by late volcanic spines. These spines host a medieval castle that is a landmark of the Bohemian Paradise area in northeast Czech Republic.

Paleomagnetic and AMS samples were collected from 29 sites, including the conduits, lava flows, and dikes intruding the conduits. The AMS data reveal magmatic flow directions that were variable, vertical (upward and downward) as well as subhorizontal (into and away from the volcano). Paleomagnetic data from the conduits and lava flows yield reverse polarity directions that are statistically indistinguishable from the expected mid-Miocene reverse polarity field direction. The dikes, however, show both normal and reverse polarity magnetizations that are statistically distinct from the expected field direction. We documented significant compositional variability of lavas erupted from the Trosky volcano, in contrast to the uniform composition of later plugs and dikes. The variability of lavas (olivine-rich, olivinepoor, clinopyroxene-rich and olivine-clinopyroxene equal types) suggests magma storage in a zoned shallow magma chamber (containing olivine- or clinopyroxene-depleted/enriched zones). The combined results and the presence of both normal and reverse polarity magnetizations from the dikes crosscutting the volcano indicate that this monogenic system was long-lived. Taken together, the simple external structure of monogenetic volcanoes often hides a rather complex magmatic plumbing system that dynamically evolves during their lifespan.

Keywords: anisotropy of magnetic susceptibility (AMS), Bohemian Massif, feeding system, paleomagnetism, scoria cone Received: May 25, 2015; accepted: August 27, 2015; handling editor: J. Žák

The online version of this article (doi: 10.3190/jgeosci.196) contains supplementary electronic material.

\section{Introduction}

Constraining the dynamics of magma flow behavior and the processes that control the evolution of volcanic development is an important task for volcanology. Volcanic activity is very common along tectonic rift systems such as the Rio Grande rift (Chapin and Seager 1975 ) and the European Cenozoic rift system (Ziegler and Dèzes 2006). As the crust becomes thinner and weaker during the extension, the upper mantle often partially melts due to decompression. Then the magma ascends and ultimately is emplaced into the crust or intersects the Earth's surface as volcanic eruption. Monogenetic volcanic cones are common along tec- tonic rift systems and they often exhibit a deceptively simple morphology. Mafic monogenetic volcanoes are generally expected as simple and probably also easypredictable volcanic systems (e.g., Pérez-López et al. 2011). Recent studies show, however, that even small basaltic volcanoes may display a complex sub-volcanic structure (e.g., Petronis et al. 2013), long-lived magmatic emplacement within the volcanic system, and unpredictable scenarios including the production of mafic pyroclastic flows (Rosi et al. 2006; Di Roberto et al. 2014). Therefore, monogenetic volcanoes with extraordinary structures or set in unusual environments are studied with an aim to understand the behavior of such volcanic systems. 


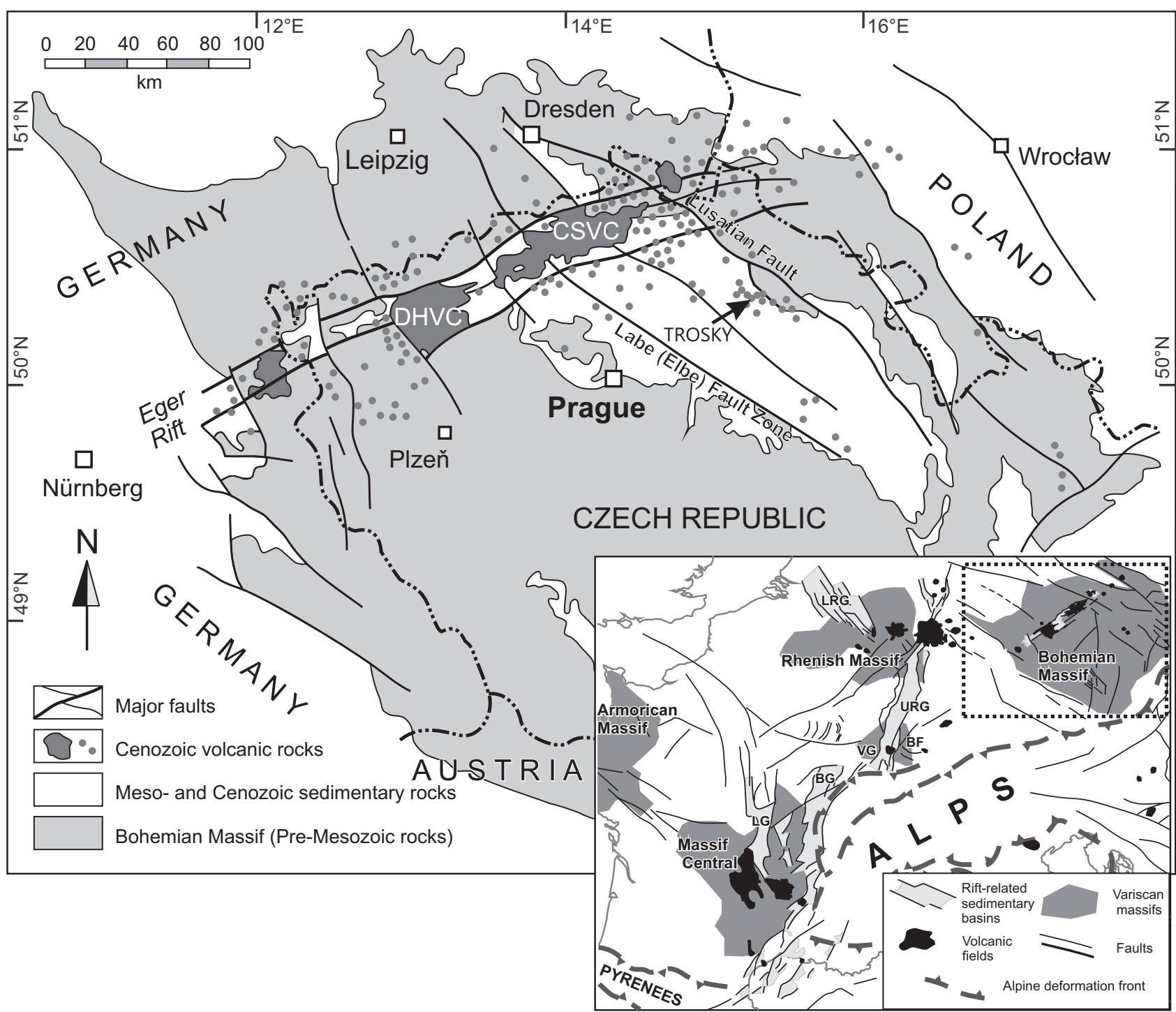

Fig. 1 Position of the Bohemian Massif within the European Cenozoic Rift System (inset). The Jičín Volcanic Field is located south of the NESW trending Eger Rift on the north-eastern margin of the Bohemian Cretaceous Basin. BF $=$ Black Forest, $\mathrm{BG}=\mathrm{Bresse}$ Graben, $\mathrm{CSVC}=\check{\mathrm{C}} \mathrm{eské}$ středohoří Volcanic Complex, DHVC = Doupovské hory Volcanic Complex, LG = Limagne Graben, LRG $=$ Lower Rhine Graben, URG $=$ Upper Rhine Graben, VG = Vosges. Position of the Trosky volcano is also indicated. Adapted after Ziegler and Dèzes (2006) and Holub et al. (2010).

Here we present the results from a detailed paleomagnetic, anisotropy of magnetic susceptibility (AMS), and structural study of the magma feeder system of the midMiocene Trosky volcano located in the Jičín Volcanic Field, Czech Republic. These data allowed us to decipher the evolution of subvolcanic deformation, the magma plumbing system geometry, eruptive dynamics, and the outer scoria cone morphology. We tested the hypothesis that some monogenetic cones conceal multiple magma conduits and evolved by long-lived volcanic activity. The results from this study challenge long-standing models that have envisioned monogenetic volcanic constructs as a single conduit with a single eruptive event (e.g., Wood 1980; Pérez-López et al. 2011; Hintz and Valentine 2012).

\section{Geological setting}

The Bohemian Massif in Central Europe experienced extensive magmatic/volcanic activity in several periods during Cenozoic (e.g., Ulrych et al. 2011 and references therein). The within-plate alkaline magmas were probably derived from upper mantle due to extension-controlled isothermal decompression. Most of the magmatism was concentrated along the Eger Rift which represents the easternmost branch of the European Cenozoic Rift System (e.g., Dèzes et al. 2004; Rajchl et al. 2008). Apart from the main volcanic complexes (see e.g., Cajz 2000; Rapprich and Holub 2008; Cajz et al. 2009; Holub et al. 2010), several volcanic fields were formed on the shoulders of the rift. Our study area is located in the Jičín 
Volcanic Field (Rapprich et al. 2007; Fig. 1) in the southeast of the Eger Rift, where Miocene volcanic rocks were emplaced into, or erupted onto, Upper Cretaceous marine sediments of the Bohemian Cretaceous Basin and continental Permo-Carboniferous strata of the Krkonoše Piedmont Basin. This area experienced only a moderate degree of erosion since the Miocene exposing features of the magma feeding systems as well as preserved superficial facies of volcanic edifices.

The tectonic framework in the wider area of the Jičín Volcanic Field located south of the NE-SW trending Eger Rift was influenced by the structure of the Bohemian Cretaceous Basin. The basin formed in a dextral strikeslip system of NW-SE orientation (nearly perpendicular to the trend of Eger Rift; Fig. 1) with two dominant fault systems; Labe Fault Zone and Lusatian Fault Zone (e.g., Uličný 2001; Uličný et al. 2009; Coubal et al. 2014). The NW-SE trending system of faults controlled the formation of the basin and remained prominent till recent times. It was associated with NNW-SSE trending synthetic and $\mathrm{N}-\mathrm{S}$ trending antithetic Riedel-shears. The distribution of the Cenozoic volcanic rocks follows these dominant fault systems as they controlled the magma ascent (Vaněčková et al. 1993). The $\mathrm{E}-\mathrm{W}$ trending tectonic grain (observed e.g. on the arrangement of the Trosky conduits), however, was the leading factor that influenced the geometry of the dikes and magma feeder conduits at shallow crustal depths (Rapprich et al. 2007).

Volcanic activity in the Jičín Volcanic Field occurred in the form of scattered Strombolian eruptions from multiple volcanic centers producing picrobasalt, basanite and olivine nephelinite lava flows, lava lakes, phreatomagmatic craters, and scoria- and tuff-cones (Rapprich et al. 2007). The volcanic eruptions occurred during two separate episodes, in the Miocene (16-19 Ma) and early Pliocene (4-5 Ma), and are characterized by intra-plate alkaline basalts, including olivine nephelinite, basanite, and picrobasalt (Rapprich et al. 2007).

The Trosky volcano is a prominent feature on the scenery rising above the surrounding volcanic hills and sandstone landscape forming two spectacular rock-towers (Fig. 2). These two rock-towers (taller Panna $=$ Virgin in Czech, $514 \mathrm{~m}$ a.s.l.;

Fig. 2 Photograph of the Trosky volcanic remnant. The lower peak on the left is the Baba conduit and the one on the right is the Panna conduit. View from south. shorter Baba = Granny in Czech, $504 \mathrm{~m}$ a.s.1.) are about $45 \mathrm{~m}$ thick each and rise some $130 \mathrm{~m}$ above surrounding surface. The Trosky volcano erupted $16.49 \pm 0.79 \mathrm{My}$ ago (K-Ar bulk-rock: Rapprich et al. 2007) and consists of basanite, mantled by remnants of scoriaceous deposits. The clast-supported scoria represents an erosional remnant of a former scoria cone.

The volcano intrudes Upper Cretaceous Turonian deltaic sediments (also known as the Hrubá Skála Sandstone Rock City) that consist mostly of well-sorted quartz sandstones (Fig. 3) overlain by a thin layer of claystones (Čech et al. 2013). The sandstones are intensively fractured with pseudokarst system developed in the area of Trosky.

\section{Methods}

\subsection{Field methods}

The fieldwork included detailed mapping of alternating lithologies, mapping sedimentary structures in pyroclastic deposits, fracture pattern geometry, and other kinematic indicators. Inaccessible exposures were photographed by a remote-controlled helicopter (www.skycam.cz). To assess the evolution of the Trosky volcano, twenty-nine sites were selected that exhibited different volcanic features for descriptions of the plumbing system and eruption dynamics. At each site, eight to fourteen oriented drill-cores were sampled using a portable gasoline-powered drill with a nonmagnetic diamond-tipped bit. All samples were oriented using a magnetic, and when possible, a solar compass reading. Samples were collected from intrusive magma conduits

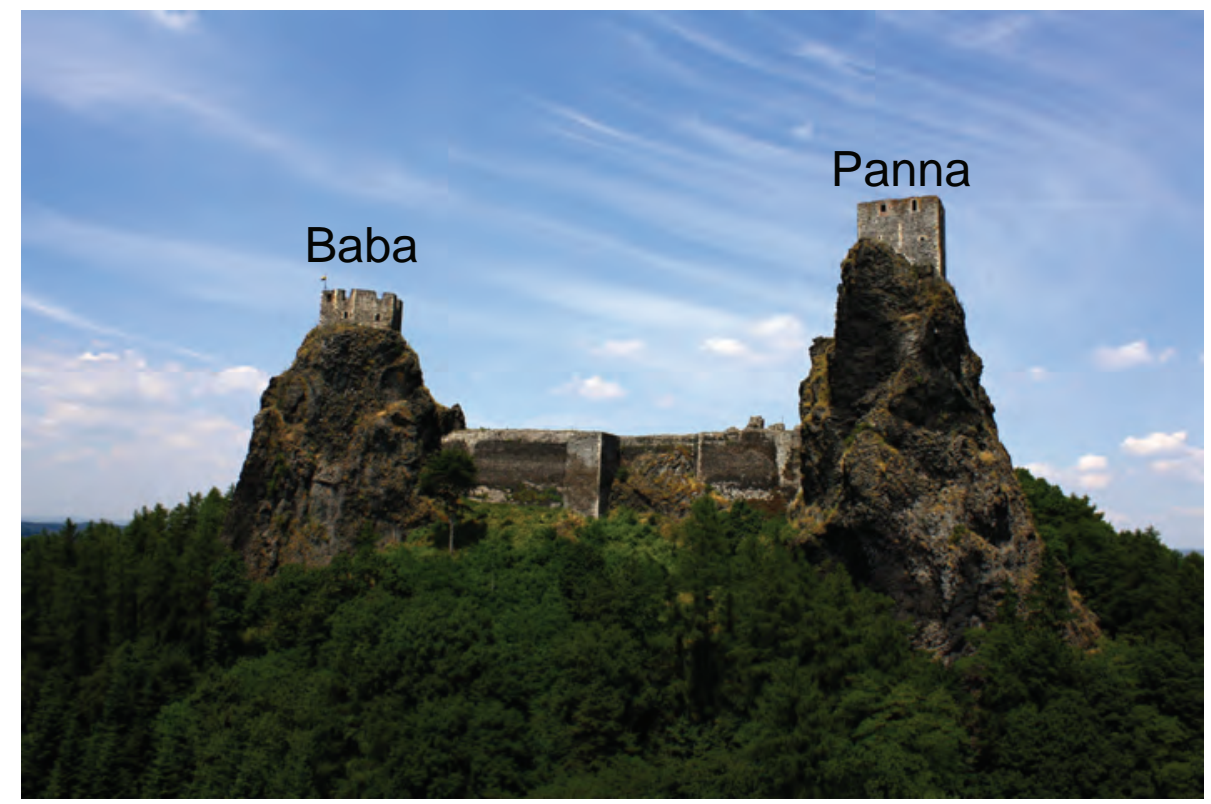


a
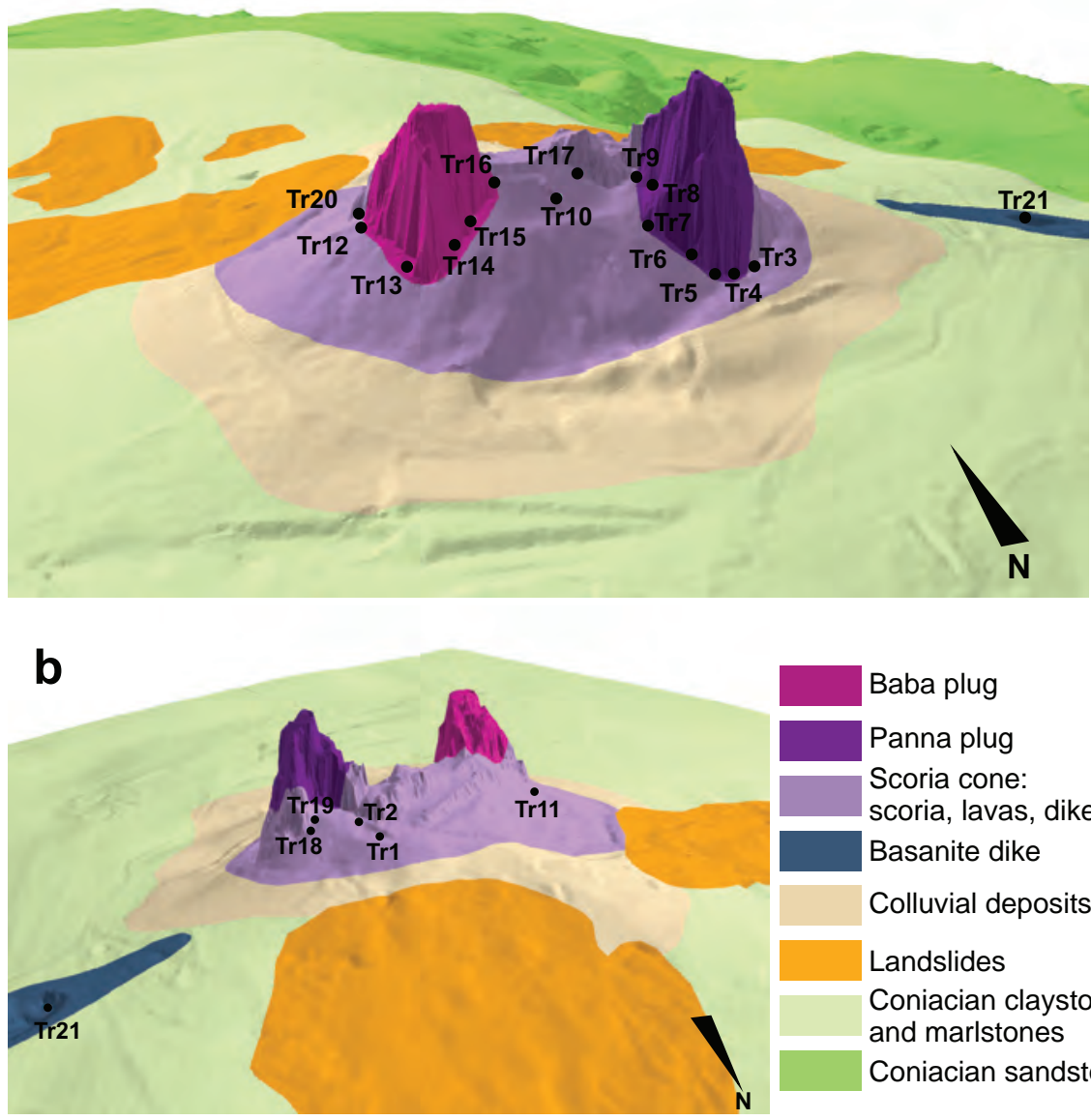

(11 sites), lava flows and tubes (5 sites), dikes (12 sites), and a scoria bomb (1 site). Samples from the dikes were collected along paired margins and across the center of the intrusion. All sampling sites were precisely located using a GPS Garmin Model 62st. All core samples were cut into cylinder specimens $(2.5 \mathrm{~cm}$ in diameter, $2.2 \mathrm{~cm}$ height), using a diamond-tipped, non-magnetic saw blade with up to three specimens per sample obtained at New Mexico Highlands University's Rock Processing laboratory.

\subsection{Paleomagnetic methods}

Remanent magnetizations of all samples were measured at New Mexico Highlands University PaleomagneticRock Magnetism laboratory using an AGICO JR6A dual-speed spinner magnetometer. Specimens were progressively alternating field (AF) demagnetized, typically in 15 to 30 steps in small intervals of $5 \mathrm{mT}$, from $5 \mathrm{mT}$ to a maximum field of $120 \mathrm{mT}$ using a ASC Scientific D-TECH 2000 AF-demagnetizer. Samples with high coercivity were treated with thermal demagnetization $(\mathrm{TH})$
Baba plug

Panna plug

Scoria cone: scoria, lavas, dikes

Basanite dike

Colluvial deposits

Landslides

Coniacian claystones and marlstones

Coniacian sandstones Courtillot 2002).
Fig. 3 Lidar-based digital elevation model of the Trosky volcano, viewed from SSW (a), and NNE (b). Geology adopted after Čech et al. (2013). Shown are also locations of 21 sites throughout the volcano with eleven sites in the conduits, five in dikes cutting the conduits, four lava flows, and one volcanic bomb within scoria deposit.

up to a maximum temperature of $630^{\circ} \mathrm{C}$. Thermal demagnetization experiments were conducted on replicate specimens to compare with AF behavior using an ASC Scientific TD48 thermal demagnetizer. Principal component analysis (PCA) was used to determine the best-fit line through selected demagnetization data points for each sample (Kirschvink 1980). Magnetization vectors with maximum angular deviation values greater than $5^{\circ}$ were not included in site mean calculations. For most samples, a single line could be fitted to the demagnetization data points. Best-fit magnetization vectors involved 5 to 18 data points, but as few as 3 to as many as 25 were used. For less than $10 \%$ of the demagnetization results, it was necessary to anchor the magnetization vector to the origin. Individual sample directions were considered outliers and rejected from the site mean calculation if the angular distance between the sample direction and the estimated site mean was greater than $18^{\circ}$. Site mean data were compared to the mid-Miocene expected field direction $\left(\mathrm{D}=359.3^{\circ}, \mathrm{I}=63.9^{\circ}, \alpha_{95}=5.2^{\circ}\right)$ based on data from the Vogelsberg Volcanic Field, Germany (Besse and 


\subsection{Anisotropy of Magnetic Susceptibility (AMS)}

Anisotropy of magnetic susceptibility measurements of a rock specimen yield an ellipsoid of magnetic susceptibility $(\mathrm{K})$ defined by the length and orientation of its three principal axes, $\mathrm{K}_{1} \geq \mathrm{K}_{2} \geq \mathrm{K}_{3}$, which are the three eigenvectors of the susceptibility tensor (Tarling and Hrouda 1993). The long axis of the magnetic susceptibility ellipsoid, $\mathrm{K}_{1}$, gives the magnetic lineation, while the short axis, $\mathrm{K}_{3}$, defines the normal to the magnetic foliation plane $\left(\mathrm{K}_{1}-\mathrm{K}_{2}\right)$. The bulk magnetic susceptibility $\left(\mathrm{K}_{\mathrm{m}}\right)$ is the arithmetic mean of the principal axes $\mathrm{K}_{1}, \mathrm{~K}_{2}$ and $\mathrm{K}_{3}$. In addition, the AMS technique defines the degree of magnitude of the linear $\left(\mathrm{L}=\mathrm{K}_{1} / \mathrm{K}_{2}\right)$ and planar $(\mathrm{F}=$ $\mathrm{K}_{2} / \mathrm{K}_{3}$ ) fabric components. The technique also quantifies the corrected degree of anisotropy, $P_{j}=\exp \left(2\left[\left(\eta_{1}-\eta\right)^{2}+\right.\right.$ $\left.\left.\left(\eta_{2}-\eta\right)^{2}+\left(\eta_{3}-\eta\right)^{2}\right]^{1 / 2}\right)$, where $\eta_{1}=\ln K_{1}, \eta_{2}=\ln K_{2}, \eta_{3}$ $=\ln \mathrm{K}_{3}$, and $\eta=\ln \left(\mathrm{K}_{1}+\mathrm{K}_{2}+\mathrm{K}_{3}\right)^{1 / 3}$. A value of $\mathrm{P}_{\mathrm{j}}=1$ describes a perfectly isotropic fabric, a $P_{j}$ value of 1.15 corresponds to a sample with an approximate $15 \%$ anisotropy and so on. Following the above, $\mathrm{P}_{\mathrm{j}}$ values of $0-5 \%$ indicate a weak anisotropy, 5-10 \% moderate anisotropy, $10-20 \%$ a strong anisotropy, and $>20 \%$ a very strong anisotropy. The shape of the susceptibility ellipsoid (T) $\left(\right.$ with $\left.\mathrm{T}=\left(2 \ln \mathrm{K}_{2}-\ln \mathrm{K}_{1}-\ln \mathrm{K}_{3}\right) /\left(\ln \mathrm{K}_{1}-\ln \mathrm{K}_{3}\right)\right)($ Jelínek 1981) ranges from +1 where purely oblate to -1 where purely prolate, and is triaxial near zero. We measured the AMS of 422 specimens prepared from samples collected at 29 sites ( 21 points: $\operatorname{Tr} 01-\operatorname{Tr} 21$, some of them with several sites (A, B, C) across the dike) distributed throughout the Trosky volcano (Fig. 3; Tab. 1). The AMS measurements were performed on an AGICO MFK1-A multi-function kappabridge operating at low alternating field of $200 \mathrm{~A} / \mathrm{m}$ at $976 \mathrm{~Hz}$ (New Mexico Highlands University Paleomagnetic-Rock Magnetic laboratory).

\subsection{Rock magnetism}

In order to characterize the magnetic mineralogy, we conducted a suite of rock magnetic experiments with the principal goal of identifying the mineral phase(s) that carry the overall remanence, the AMS fabric, the quantity, composition, and grain size of the magnetic phase(s) present, and testing whether the materials carry a geologically stable remanence. Rock magnetic experiments included (1) analysis of low-field susceptibility versus temperature, (2) isothermal remanent magnetization (IRM) and backfield IRM experiments (coercivity of remanence), and (3) modified Lowrie-Fuller test involving the demagnetization of the natural remanent magnetization (NRM), anhysteretic remanent magnetization (ARM), and saturation IRM (SIRM). All susceptibility experiments were measured with an AGICO MFK1-A kappabridge susceptibility meter operating at $976 \mathrm{~Hz}$ with an applied field of $200 \mathrm{~A} / \mathrm{m}$. Isothermal magnetizations were imparted using an in-house built static impulse magnet, and magnetic remanence was measured on an AGICO JR6A dual-speed spinner magnetometer.

\section{Results}

\subsection{Lithologies}

The Trosky volcano consists of a pair of nearly vertical conduits emplaced in Cretaceous sedimentary country rocks with multiple dikes propagating through welded and non-welded scoria of various orientations. The detailed volcanological and structural study enabled us to distinguish four main structural and lithological types exposed on the Trosky volcano: scoria deposits, lava flows, dikes, and the main conduits (plugs).

\subsubsection{Scoria deposits}

The scoria deposits are poorly sorted, clast-supported and non-welded. Fragments of irregular scoria of variable size enclose larger spindle-shaped bombs. Larger scoria clasts and some of the bombs contain xenoliths of underlying Cretaceous sedimentary rocks. At the outcrop, where bed-

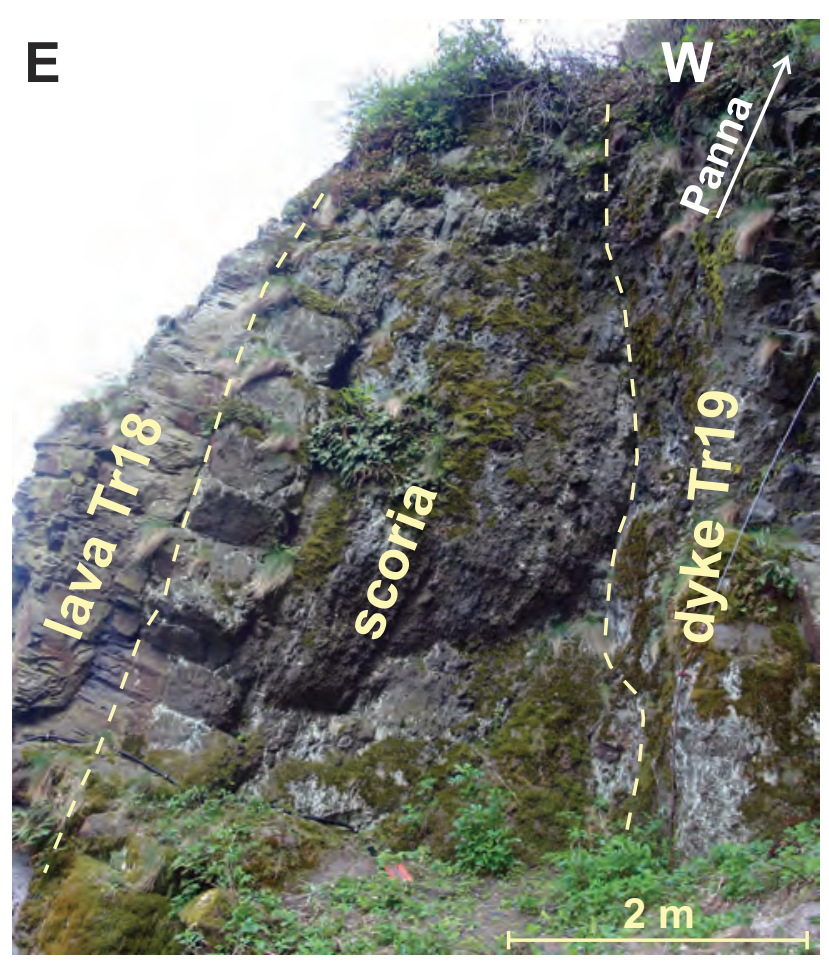

Fig. 4 Eastern margin of the Panna plug: steeply dipping strata of scoria deposits with lava ( $\operatorname{Tr} 18$ to the left) and penetrated by dike (Tr19 to the right). 

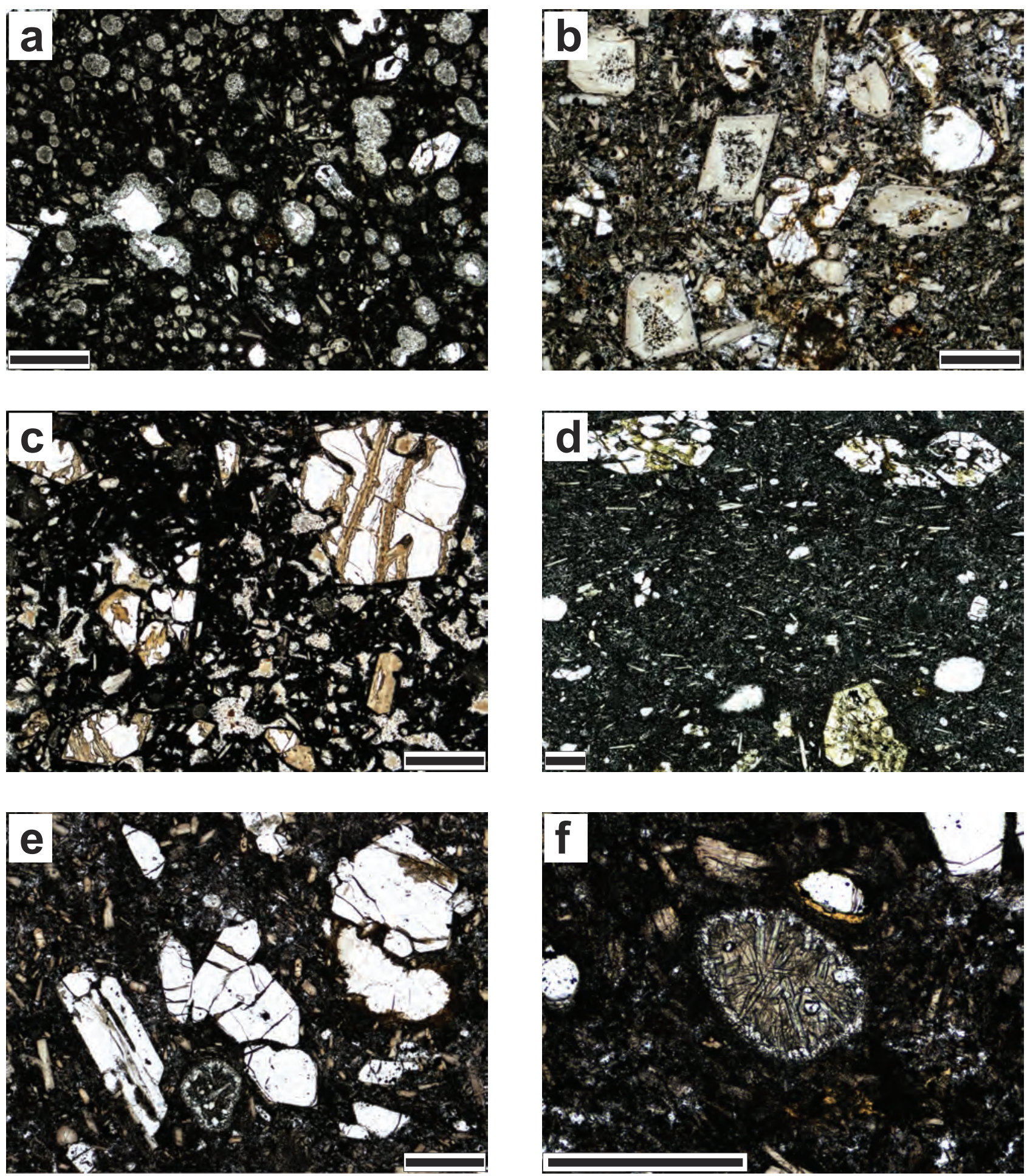

Fig. 5 Photomicrographs of main lithological types. a - Volcanic bomb in scoria deposit (sample Tr20): dark groundmass with frequent needles of clinopyroxene contains abundant vesicles filled with zeolites; $\mathbf{b}$ - Lava from Baba (sample Tr17): abundant idiomorphic phenocrysts of clinopyroxene outweigh olivine by volume in medium-grained groundmass of clinopyroxene, magnetite, plagioclase and nepheline; $\mathbf{c}$ - Lava from Panna (sample $\operatorname{Tr} 18)$ : large phenocrysts of olivine enclosed in dark groundmass with tiny needles of clinopyroxene and irregular vesicles filled with zeolites; d - Dike (sample Tr19): bands of variable degree of preferred orientation, olivine phenocrysts in groundmass of oriented (left top to right bottom) clinopyroxene needles and plagioclase laths, magnetite and nepheline; $\mathbf{e}$ - Baba plug (sample Tr14): olivine phenocrysts and pseudomorph (bottom center) after quartz in groundmass of clinopyroxene, magnetite, olivine, plagioclase and nepheline; $\mathbf{f}$ - Detail on pseudomorph (clinopyroxene and glass) after quartz in basanite of the Panna plug (sample Tr05). Scale bar in all images is $0.5 \mathrm{~mm}$, all images in plane-polarized light. 
ding is exposed, the strata dip up to $75-80^{\circ}$ (Fig. 4). Scoria deposits contain larger bombs of densely vesiculated basanite with olivine phenocrysts (up to $0.4 \mathrm{~mm}$, scarcely up to $2 \mathrm{~mm}$ ) and acicular clinopyroxene not exceeding $0.4 \mathrm{~mm}$ in length (Fig. 5a). The vesicles are rounded or oval and filled with zeolite (most likely analcite). The pseudomorphs after quartz grains occur scarcely within scoria clasts. The groundmass in the bombs comprises two distinct facies. In the bomb's core, the groundmass consists of dark, weakly translucent submicroscopic mixture of $\mathrm{Fe}-\mathrm{Ti}$ oxides, plagioclase and nepheline/analcite. On the other hand, the oxidation colored the groundmass to a deep red at the margins.

\subsubsection{Lavas}

The scoria beds are at several sites interbedded with lava flows, comprising lava-tube structures (Fig. 6). In between the both plugs, a $5 \mathrm{~m}$ thick columnar-jointed lava (Tr17) is exposed including a smaller lava-tube with scale-structures that indicate downward magma flow. The tube itself has oval profile about $50 \mathrm{~cm}$ across and $30 \mathrm{~cm}$ in height. The surface of this lava is brecciated with individual lava fragments $c .75 \mathrm{~cm}$ in diameter. Smooth surface of another lava $(\operatorname{Tr} 10)$ with striations parallel to the flow direction is located some $20 \mathrm{~m}$ to the south of the first lava tube. The second lava with a lava-tube can be found hanging steeply tilted on the eastern side of Panna tower (not accessible for sampling). The lava-tube is half-filled with lava and has remaining open space about $1 \mathrm{~m}$ across and $30 \mathrm{~cm}$ in height. The intrusion of Panna plug tilted to a steep position about $1 \mathrm{~m}$ thick lava (Tr18) with smooth and sharp contacts to scoria underneath and above.

The petrography of studied lavas is much more variable compared to later dikes and plugs. The $\operatorname{Tr} 10$ lava is finely porphyritic with up to $0.4 \mathrm{~mm}$ large phenocrysts of olivine and $1.5 \mathrm{~mm}$ glomerocrysts of clinopyroxene consisting of several $1 \mathrm{~mm}$ long needles. The volume of olivine phenocrysts and clinopyroxene phenocrysts including glomerocrysts (excluding fine clinopyroxene in groundmass) is nearly equal. The phenocrysts and scarce pseudomorphs (radially arranged clinopyroxene and

Fig. 6 Field photograph of the lava tube structure $(\operatorname{Tr} 17)$. The diameter of the lava tube is $50 \times 30 \mathrm{~cm}$ and the tube is dipping towards east with dip amount c. $35^{\circ}$. isotropic glass) after quartz, $0.2 \mathrm{~mm}$ across, are enclosed in fine groundmass represented by mixture of clinopyroxene, magnetite, plagioclase and nepheline/analcite. The lava sampled at $\operatorname{Tr} 17$, which seems to be similarly as Tr10 erupted from Baba, differs significantly in modal composition. Frequent clinopyroxene phenocrysts (commonly 0.5 , rarely $1 \mathrm{~mm}$ in size) overweigh scarce olivine (up to $0.5 \mathrm{~mm}$ ) by volume (Fig. $5 \mathrm{~b}$ ). The phenocrysts are enclosed in medium-grained groundmass consisting of clinopyroxene, olivine, magnetite, plagioclase and nepheline. The lava sampled on the north-eastern side of Panna (Tr18) is dominated by large (commonly $1 \mathrm{~mm}$ ) phenocrysts of olivine. Clinopyroxene does not form phenocrysts and is present solely in groundmass as tiny needles (Fig. 5c). The groundmass is dark and fine grained, and thus no other mineral phases can be identified. There are frequent irregular vesicles not exceeding $0.5 \mathrm{~mm}$ in size, filled with zeolites and/or carbonates.

\subsubsection{Dikes}

The dikes, $0.3-1.5 \mathrm{~m}$ wide, are locally branching and binding scoria deposits, mostly following the scoria bedding planes but also crossing them. Dike margins/ contact zones are $2-3 \mathrm{~cm}$ wide and chilled against very fine-grained, non-vesiculated scoria. The vesicles at the margins are sheared and imbricated in the direction of flow and also the mm-sized vesicles in the center are parallel and elongated in the direction of flow. At the base of Panna, columnar joints distinguished dikes and conduit from the welded scoria. There are massive basalt columns with step-down chatter marks and near vertical slickensides that indicate upward magma flow. There are steep "V" like grooves between the massive

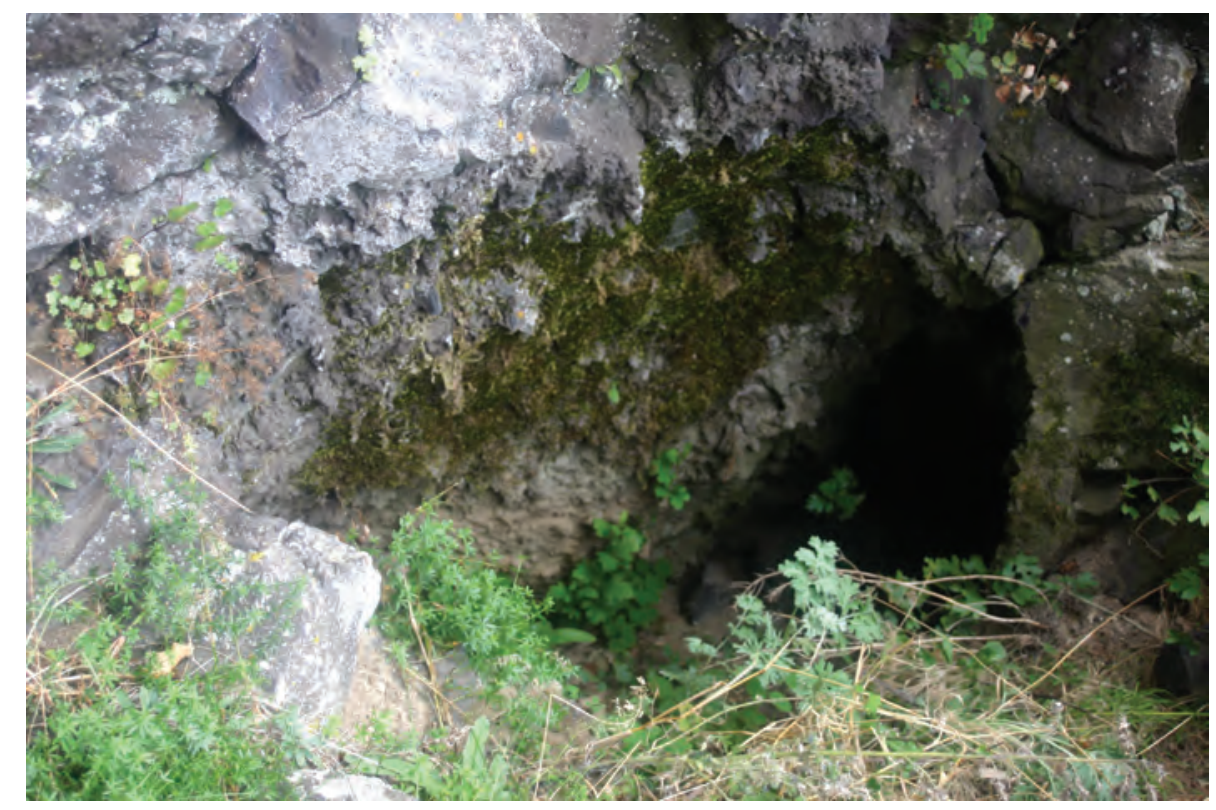




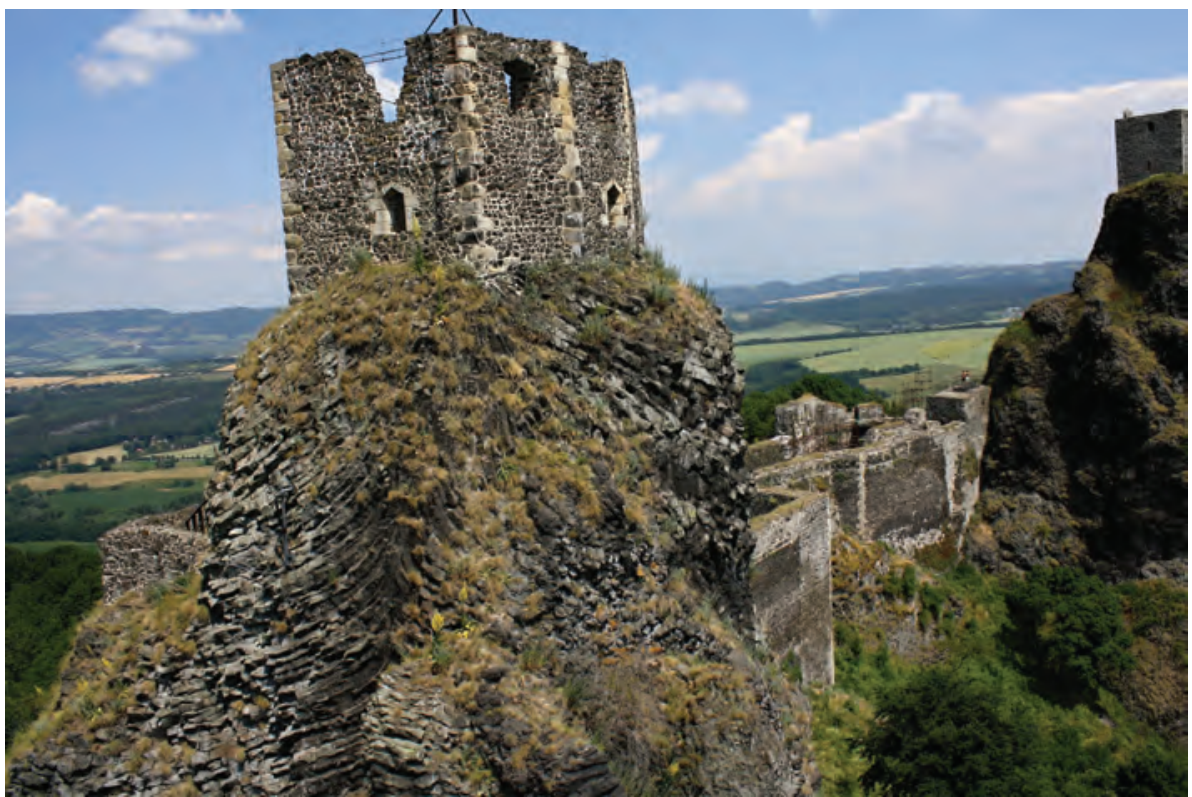

Fig. 7 Photograph from the remotecontrolled helicopter of the Baba conduit that displays downward-facing fan-arranged columnar jointing. View from west. contracted polygonal columns. Most of the Baba dikes lack conspicuous columnar jointing. The basanite dike $\operatorname{Tr} 19$ contains scarce phenocrysts of olivine (up to $2 \mathrm{~mm}$; Fig. 5d top) and clinopyroxene (up to $2 \mathrm{~mm}$; Fig. 5d bottom) enclosed in strongly flow-foliated groundmass. Namely clinopyroxene needles and plagioclase laths display strong arrangement among isometric microcrysts of magnetite and anhedral nepheline.

\subsubsection{Conduits}

The main conduits represented by two plugs were sampled only on the margins as the interior is not exposed. The conduits contain abundant sandstone and marlstone xenoliths $(1-10 \mathrm{~cm}$, occasionally up to $1.5 \mathrm{~m}$ in diameter). The larger sandstone xenoliths show columnar jointing, due to volume changes of moist sediment when enclosed in hot magma. Columnar jointing of the plugs is arranged in form of upside-down fan (Fig. 7). The rock of the both plugs is very similar and consists of olivine phenocrysts (up to $1 \mathrm{~mm}$ ) and abundant pseudomorphs (clinopyroxene and glass) after quartz grains $(0.05-0.5 \mathrm{~mm})$ enclosed in groundmass of clinopyroxene, olivine, magnetite, plagioclase and nepheline (Fig. 5e-f).

\subsection{Anisotropy of Magnetic Susceptibility}

Magnetic susceptibility data for all sites are summarized in Tab. 1 together with all principal magnetic parameters measured. Of the 29 sites analyzed for AMS, the relationship between the corrected degree of anisotropy, $\left(\mathrm{P}_{\mathrm{j}}\right)$ and bulk susceptibility $\left(\mathrm{K}_{\mathrm{m}}\right)$ shows a weak correlation between the samples with a poorly defined trend through the conduit, dike, and volcanic bomb (Tab. 1). The corrected degree of anisotropy $\left(\mathrm{P}_{\mathrm{i}}\right)$ versus the shape parameter (T) data plots dominantly in the prolate field and there is no correlation between the $\mathrm{T}$ and $\mathrm{P}$ values (Fig. 8). Twelve of the 21 sites are in dikes and can be used to interpret magma flow (Tab. 1). The corrected degree of anisotropy $\left(\mathrm{P}_{\mathrm{j}}\right)$ of the 12 accepted sites is relatively low and varies from $0.2 \%\left(\mathrm{P}_{\mathrm{j}}=1.002\right)$ to $1 \%\left(\mathrm{P}_{\mathrm{j}}=\right.$ 1.01) (Tab. 1). Of the 12 dikes

Fig. 8 The $P_{j}$ vs. T diagram of the AMS data. 


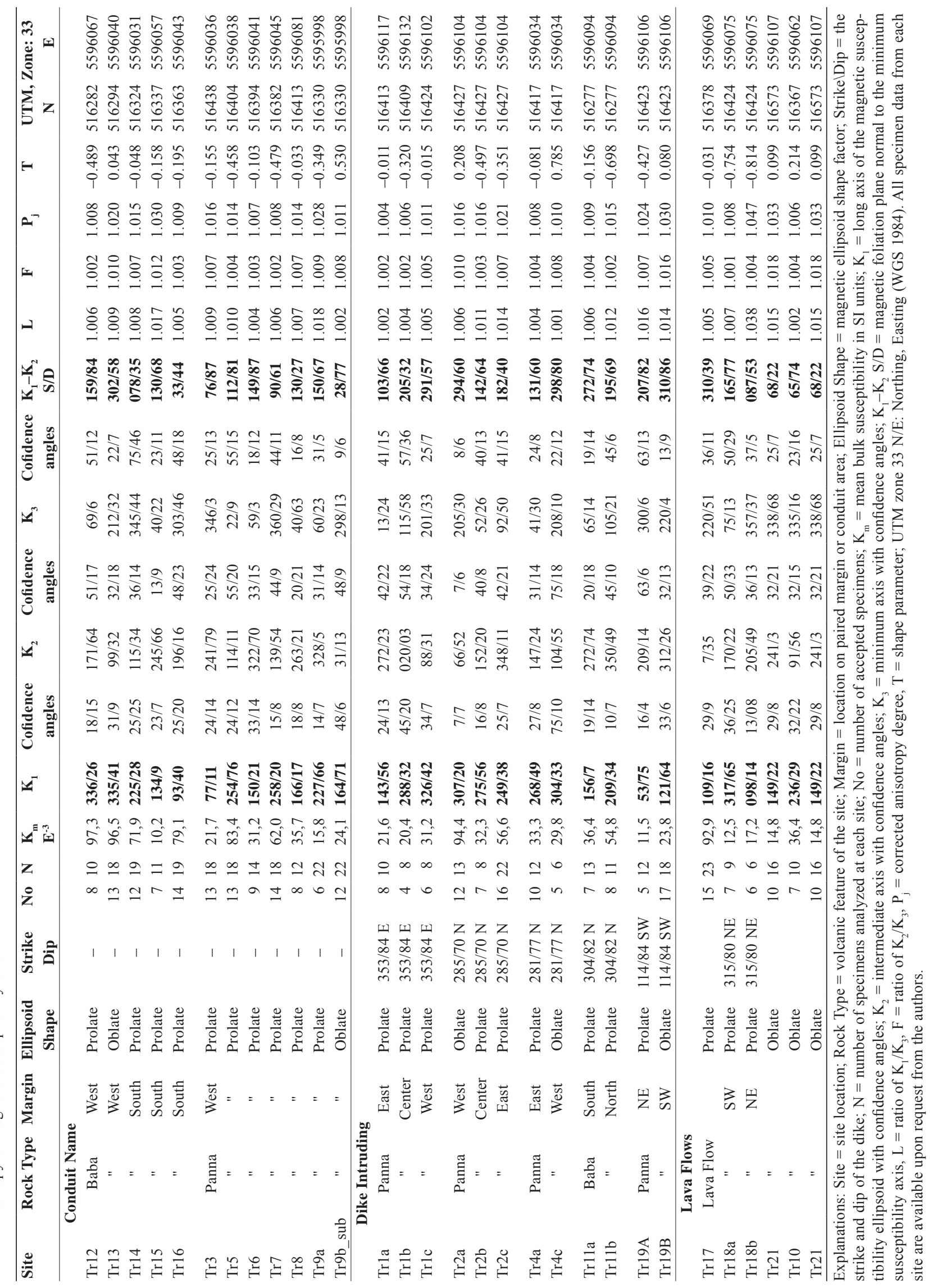


sites, $88 \%$ have a prolate, and only $12 \%$ have roughly triaxial or oblate susceptibility ellipsoids.

\subsection{Paleomagnetism}

\subsubsection{General demagnetization behavior}

Of the 21 sample sites collected at the Trosky volcano for paleomagnetic analysis, twenty sites yield interpretable demagnetization results (Tab. 2). The overall progressive AF demagnetization response from all rock types is characterized by a near linear trend to the origin for most samples that is defined over a broad range of peak fields and temperatures. Most samples yielded a single-component magnetization that decayed linearly to the origin with less than $10 \%$ of the NRM remaining after treatment in $120 \mathrm{mT}$ applied field. A few samples contained additional low coercivity viscous remanent magnetization (VRM) components that were readily randomized by $20 \mathrm{mT}$ (Fig. 9). Once the VRM was removed, the remaining magnetization decayed along a linear trend to the origin with less than $10 \%$ of the NRM remaining after $120 \mathrm{mT}$ applied field.

\subsubsection{Dikes}

Paleomagnetic data were obtained from four dikes that intrude Panna and one dike intruding Baba. Three of the four dikes from Panna yielded well-defined reverse polarity magnetization directions, one site a well-defined normal polarity magnetization and the one dike at Baba a well-defined reverse polarity magnetization (Tab. 2). Of the five sites, only one is statistically indistinguishable at 95\% confidence level from the expected Miocene reverse (normal) polarity field direction.

\subsubsection{Lava flows and volcanic bomb}

Paleomagnetic data were obtained from four lava flows and one volcanic bomb within scoria. All sites yielded

Tab. 2 Paleomagnetic data from the Trosky volcano

\begin{tabular}{|c|c|c|c|c|c|c|c|c|c|c|c|}
\hline Site & Rock Type & Explanation & Strike/Dip & $n / \mathbf{N}$ & $\mathbf{R}$ & Dec & Inc & $\alpha_{95}$ & $\mathbf{K}$ & VGP Lat & VGP Long \\
\hline \multicolumn{12}{|c|}{ Intruding } \\
\hline $\operatorname{Tr} 1$ & Dike & Panna & $353 / 84$ & $13 / 15$ & 12.91 & 145.2 & -68.7 & 3.6 & 130.6 & -10.4 & -151 \\
\hline $\operatorname{Tr} 2$ & " & " & $285 / 70$ & $9 / 11$ & 44.29 & 78.1 & -67.0 & 2.7 & 62.4 & 30.2 & -31.9 \\
\hline $\operatorname{Tr} 4$ & $"$ & " & $281 / 77$ & $5 / 15$ & 76.33 & 182.2 & -65.7 & 2.4 & 46.1 & -87.1 & 14.3 \\
\hline $\operatorname{Tr} 19$ & $"$ & $"$ & $114 / 84$ & $4 / 10$ & 11.98 & 73.3 & 22.0 & 1.8 & 590.9 & 19.4 & 110.8 \\
\hline $\operatorname{Tr} 11$ & $"$ & Baba & $214 / 82$ & $6 / 13$ & 94.10 & 129.1 & -41.8 & 1.4 & 104.3 & -42.9 & 90.6 \\
\hline \multicolumn{12}{|c|}{ Conduit Name } \\
\hline $\operatorname{Tr} 3$ & Conduit & Panna & - & $11 / 15$ & 92.45 & 171.8 & -57.7 & 1.1 & 168.4 & -76.5 & 43.9 \\
\hline $\operatorname{Tr} 5$ & " & " & - & $8 / 14$ & 143.33 & 168.6 & -60.2 & 1.9 & 39.8 & -77.8 & 59.8 \\
\hline Tr6 & $"$ & $"$ & - & $9 / 18$ & 105.10 & 172.9 & -60.8 & 2.3 & 36.9 & -80 & 47.2 \\
\hline $\operatorname{Tr} 7$ & $"$ & " & - & $9 / 9$ & 147.85 & 176.6 & -63.6 & 1.9 & 36.4 & -84.3 & 40.0 \\
\hline $\operatorname{Tr} 8 *$ & $"$ & " & - & \multicolumn{8}{|l|}{ Rejected } \\
\hline \multirow[t]{2}{*}{$\operatorname{Tr} 9$} & $"$ & $"$ & - & $7 / 8$ & 69.91 & 87.7 & -61.7 & 2.9 & 33.9 & -30.4 & 137.0 \\
\hline & Mean & & & $5 / 6$ & 4.82 & 159.1 & -64.7 & 16.4 & 28.5 & - & - \\
\hline $\operatorname{Tr} 12$ & Conduit & Baba & - & $5 / 7$ & 61.20 & 157.1 & -64.2 & 1.4 & 168.0 & -74.1 & 97.4 \\
\hline $\operatorname{Tr} 13$ & " & " & - & $6 / 10$ & 39.54 & 165.8 & -80.3 & 2.5 & 84.6 & -68.4 & -177.2 \\
\hline $\operatorname{Tr} 14$ & $"$ & " & - & $5 / 9$ & 22.91 & 169.7 & -52.3 & 1.9 & 256.8 & -70.8 & 42.3 \\
\hline $\operatorname{Tr} 15^{*}$ & $"$ & " & - & $4 / 12$ & 27.67 & 127.0 & -28 & 15.7 & 3.0 & -34.6 & 85.0 \\
\hline \multirow[t]{3}{*}{$\operatorname{Tr} 16$} & $"$ & " & - & $7 / 9$ & 64.73 & 164.8 & -50.7 & 1.1 & 236.7 & -67.9 & 51.5 \\
\hline & Mean & & & $4 / 5$ & 3.912 & 164.7 & -61.9 & 16.0 & 45.5 & - & - \\
\hline & \multicolumn{3}{|c|}{ Location } & & & & & & & & \\
\hline $\operatorname{Tr} 10$ & Lava Tube & South & $\mathrm{n} / \mathrm{a}$ & $7 / 7$ & 94.40 & 175.1 & -71.3 & 2.8 & 26.9 & -83.9 & 168.5 \\
\hline $\operatorname{Tr} 17$ & Lava Flow & South & - & $8 / 10$ & 109.44 & 170.8 & -63.5 & 1.0 & 193.4 & -81.8 & 68.2 \\
\hline $\operatorname{Tr} 18$ & " & East & $315 / 80$ & $8 / 9$ & 108.14 & 171.2 & -64.1 & 1.2 & 125.0 & -82.5 & 70.5 \\
\hline \multirow[t]{3}{*}{$\operatorname{Tr} 21$} & " & South-East & - & $4 / 8$ & 23.96 & 187.2 & -62.6 & 1.2 & 652.1 & -81.8 & -24.3 \\
\hline & Mean & & & $4 / 4$ & 3.99 & 176.3 & -65.5 & 5.9 & 323.9 & - & - \\
\hline & \multicolumn{3}{|c|}{ Scoria From: } & & & & & & & & \\
\hline $\operatorname{Tr} 20$ & Bomb & Baba & $\mathrm{n} / \mathrm{a}$ & $5 / 9$ & 22.86 & 181.6 & -70.1 & 2.4 & 159.1 & -86.2 & -150.3 \\
\hline
\end{tabular}

Expected Miocene reverse polarity field direction (i.e., $\mathrm{D}=179.3^{\circ}, \mathrm{I}=-63.9^{\circ}, \alpha_{95}=5.2^{\circ}$ )

Explanations: Site = paleomagnetic sampling location; Rock Type = igneous geometry; Strike/Dip = strike and dip of the dike margin; $\mathrm{n} / \mathrm{N}=$ ratio of samples used $(\mathrm{n})$ to samples collected $(\mathrm{N})$ at each site; $\mathrm{R}=$ resultant vector length, Dec/Inc $=$ in-situ declination and inclination, $\alpha_{95}=95 \%$ confidence interval about the estimated mean direction assuming a circular distribution; $\mathrm{K}=$ best estimate of (Fisher) precision parameter; VGP Lat/Long = in-situ latitude and longitude of the virtual geomagnetic pole for the site. 

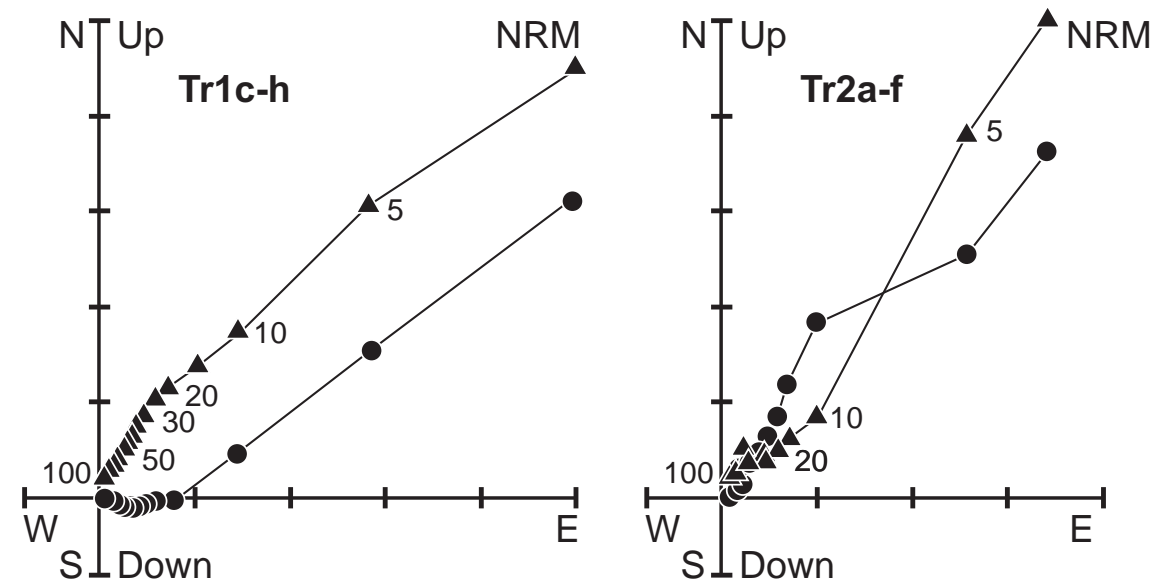

Fig. 9 Representative in-situ modified demagnetization diagrams showing the typical demagnetization behavior of the Trosky volcano (Zijderveld 1967; Roy and Park 1974). Solid circle (triangle) symbols represent the projection onto the horizontal (true vertical) plane. Diagrams are designated by a site number (e.g., $\operatorname{Tr} 1)$ and method of treatment (AF $=$ alternating field in $\mathrm{mT}$ ). Intensity $(\mathrm{A} / \mathrm{m})$ is shown along one axis for each sample, each division equals $0.524 \mathrm{~A} / \mathrm{m}$ in the upper two and $0.804 \mathrm{~A} / \mathrm{m}$ in bottom three diagrams.

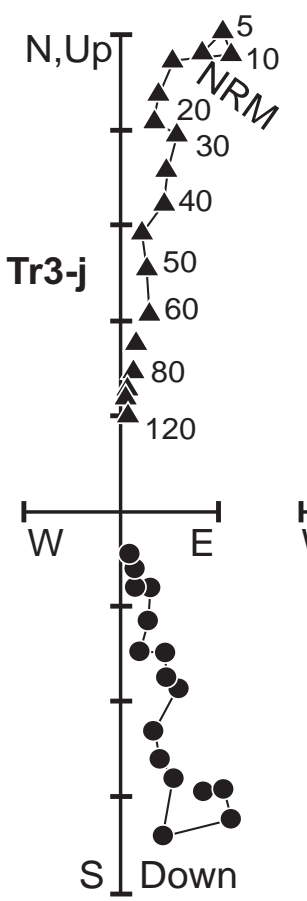

well-defined reverse polarity magnetization directions that are statistically indistinguishable at $90 \%$ (2 sites) to 95\% (3 sites) confidence level from the expected Miocene reverse (normal) polarity field direction (Tab. 2, Fig. 10).

\subsection{Rock magnetic properties}

The complete rock magnetic results are discussed in Electronic Appendix 1. In summary, the rock magnetic data indicate that the dominant magnetic mineral phase is cubic $\mathrm{Fe}-\mathrm{Ti}$ oxide of a restricted magnetic grain size between pseudosingle to multidomain titanomagnetite. Curie point estimates imply that the composition of the titanomagnetite from the majority of the sites reflects medium to high-Ti titanomagnetite. At a few sites, the thermomagnetic data reveal the presence of coarse-
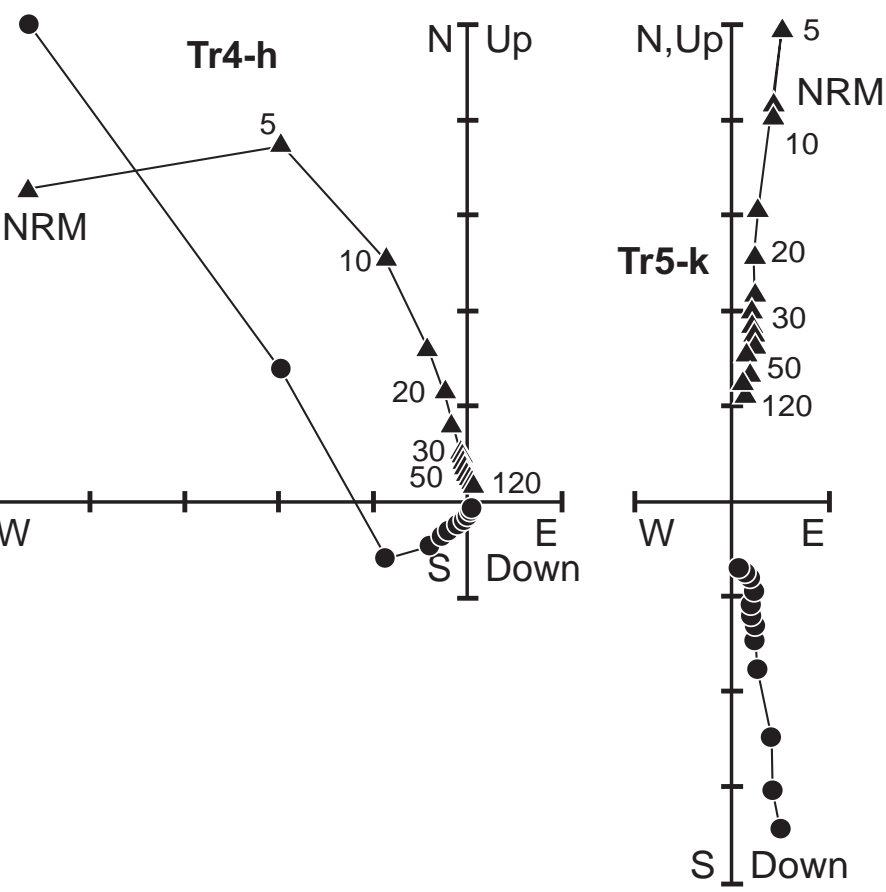

grained maghemite; low-Ti titanomagnetite occurs in a few samples.

\section{Discussion}

\subsection{AMS-inferred magma flow directions}

In order to gain an understanding of magma emplacement it is important to consider the geometry, magma flow processes, physical controls on emplacement, and the regional deformation pattern at the time of intrusion. In the simplest of circumstances, the rock fabric of crystallized magma preserves either of two end-member processes. The fabric may reflect a magma flow direction (stretching direction) because elongate minerals are often 


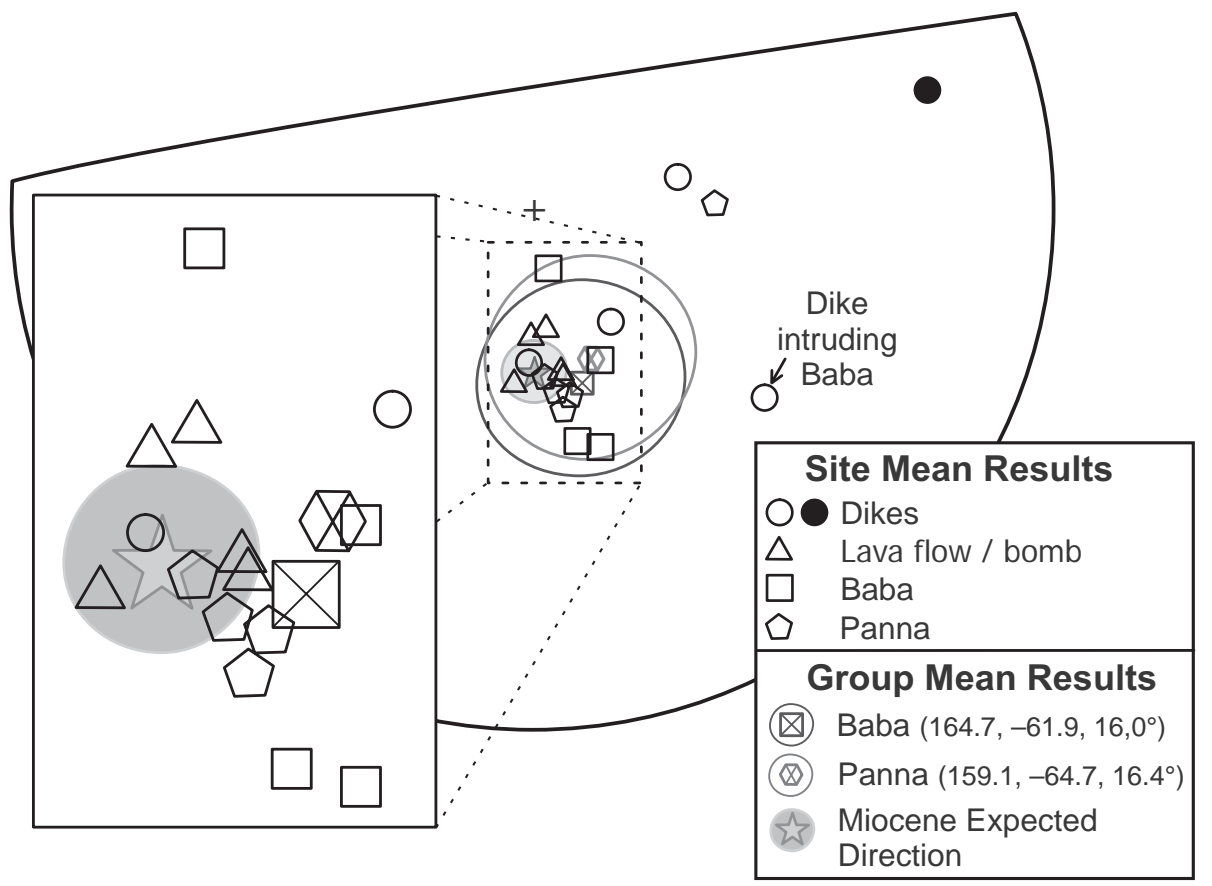

Fig. 10 Lower hemisphere, equal area projection of in-situ site mean directions for all site locations and group mean directions for Baba and Panna with associated $95 \%$ confidence ellipse. Open (solid) symbols represent reverse (normal) polarity directions. The open star with confidence ellipse is the midMiocene expected field direction (D $\left.=359.3^{\circ}, \mathrm{I}=63.9^{\circ}, \alpha_{95}=5.2^{\circ}\right)$ based on data from the Vogelsberg Volcanic Field, Germany (Besse and Courtillot 2002). Inset: Close-up of the central part of the diagram showing the dispersion between paleomagnetic data from the various sites. rotated under simple-shear into the flow-plane defining a flow-lineation. Alternatively, the magmatic foliation develops in relation to the regional orientation of the maximum principal shortening direction acting at the time of emplacement which preferentially orients most planar crystals normal to that direction (see Paterson et al., 1998 for further discussion). Unfortunately, magmatic fabrics are often difficult to measure in the field because the mineral fabric is commonly subtle and separating magmatic from regional strain fabrics is not straightforward. The low-field AMS technique can detect very weak mineral alignments and is an excellent tool for rapid, accurate measurement of petrofabrics. Moreover, to a certain extent, it provides an estimate of the amount of strain (Borradaile and Henry 1997; Bouchez 1997, 2000). Even in weakly anisotropic material, it is now widely accepted that the magnetic lineations and foliations potentially reflect the magmatic fabric and can provide information on magma migration, flow geometries, and regional strain (King 1966; Owens and Bamford 1976; Hrouda 1982; Rochette 1987; Rochette et al. 1992; Tarling and Hrouda 1993; Bouchez 1997; Borradaile and Henry 1997; Dietl 1999; Sant'Ovaia et al. 2000; Petronis et al. 2004, 2009, 2013; Horsman et al. 2005; Sidman et al. 2005; Žák et al. 2005, 2011; O'Driscoll et al. 2006; Stevenson et al. 2007; Kratinová et al. 2010). In the following, we consider the possible driving mechanisms that formed the fabrics revealed by AMS data from the Trosky volcano.

During the Early to Middle Miocene (c. 20-16 Ma), scattered volcanism was common on north-eastern margin of the Bohemian Massif (Lower Silesia; e.g., Birkenmajer et al. 2004). Volcanic activity in the Jičín
Volcanic Field was dominated by scattered Strombolian eruptions arranged predominantly along E-W trending faults. During the growth of the Trosky volcano, the principal extension direction, off axis from the dominant NE-SW principal extension associated with the Eger Rift, was likely oriented roughly perpendicular to the dominate fault trend in the region (i.e., NW-SE to NNW-SSE: Rajchl et al. 2008; Coubal et al. 2015). Coherent conduits of small volcanoes commonly follow pre-existing tectonic structures without any influence by the local stress-field caused by the volcanic construct. At the Trosky volcano, we argue that the $\mathrm{N}-\mathrm{S}$ extension did not play a role in controlling the magmatic emplacement. The magnetic fabrics revealed by the AMS data represent magma flow pattern during emplacement.

The magnetic fabrics at the Trosky volcano reveal a pattern that varies spatially across the sampled parts of the intrusions (Fig. 11). The shape parameter (T) (Jelínek 1981) is commonly used to distinguish oblate from prolate magnetic fabrics (see also Owens 1974; Jelínek 1978; Owens 2000a, b). In oblate magnetic fabrics, the planar elements dominate and the shape of the susceptibility ellipsoid is flattened in the $\mathrm{K}_{1}-\mathrm{K}_{2}$ plane. Commonly, the orientation of the $\mathrm{K}_{1}-\mathrm{K}_{2}$ susceptibility axes varies between specimens from the same sample with the overall dispersion of the two susceptibility axes defining a greatcircle girdle on a stereographic projection. Therefore, if the fabric elements at a site are strongly oblate and the $95 \%$ confidence ellipses of the $\mathrm{K}_{1}$ and $\mathrm{K}_{2}$ axes overlap in the $\mathrm{K}_{1}-\mathrm{K}_{2}$ plane, then the $\mathrm{K}_{1}$ orientation must be taken with caution and it is often not appropriate to interpret the orientation of the $\mathrm{K}_{1}$-lineation in the context of a flow 


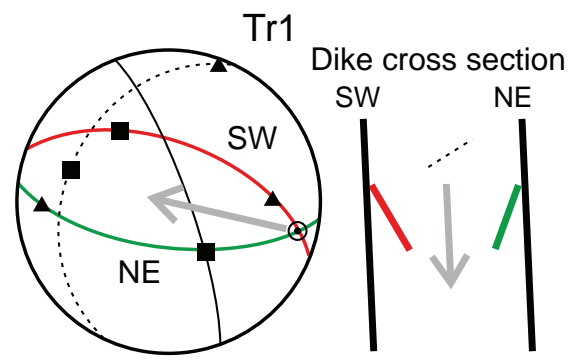

Downward inclined flow to the SW

Fig. 11 Representative anisotropy of magnetic susceptibility (AMS) results and inferred magma flow directions for four dike sites from the Trosky volcano. The results for all sites are summarized in Tab. 1. Left diagram: Lower hemisphere equal area projections of in-situ AMS principal susceptibility axes ( $\max \mathrm{K}_{1}$, squares, intermediate $\mathrm{K}_{2}$, triangles, and minimum $\mathrm{K}_{3}$, circles) from the paired dike margins (see text for discussion). Arrow with trend and plunge values indicates the direction and sense of inferred magma flow. Right diagram: a sketch cross-section or map view showing the orientation of the magnetic fabric along the paired dike margins with the direction and sense of the magma flow indicated by the arrow.

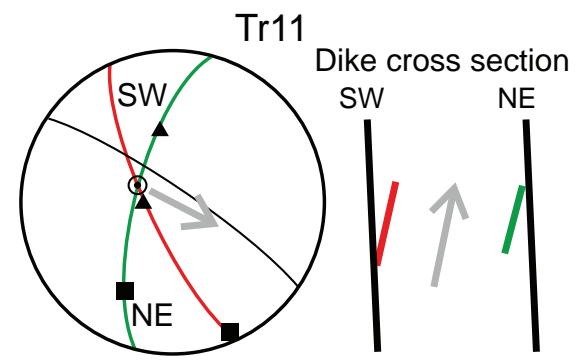

Sub-vertical flow towards the SE

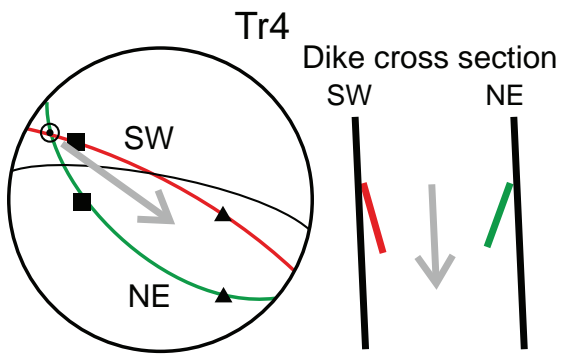

Downward inclined flow to the SE

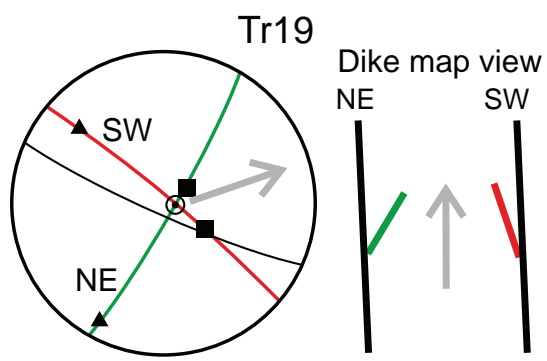

Sub-horizontal flow towards the NE

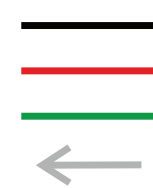
Dike margins West margin dip of magnetic ellipsoid foliation East margin dip of magnetic ellipsoid foliation Sense of flow
- Flow vector

- $\mathrm{K}_{1}$

$\Delta \mathrm{K}_{2}$ or stretching direction. Conversely, in a prolate magnetic fabric, the linear elements dominate and the shape of the susceptibility ellipsoid is elongated along the $K_{1}$ axis. When the fabric elements at a site are prolate, it is at times appropriate to interpret the orientation of the $\mathrm{K}_{1}$ lineation in the context of a flow or stretching direction; although many caveats exist when interpreting the linear fabric (e.g., Ellwood 1982; Knight et al. 1986; Hillhouse and Wells 1991; Seaman et al. 1991; Ort 1993; Geoffroy et al. 1997; Le Pennec et al. 1998; Tauxe 1998).

\subsubsection{Conduits}

The AMS fabric data from Baba and Panna yield dominantly (10 of 11 sites) prolate susceptibility ellipsoids with a low degree $(<3 \%)$ of anisotropy (Tab. 1). $\mathrm{K}_{1}$ lineations vary among sample sites depending on their location. Two sites from Baba were sampled along the west side of the conduit and yielded $\mathrm{N}-\mathrm{W}$ trending and moderately plunging $\mathrm{K}_{1}$ lineations. Three sites from the southern part of the conduit gave variably trending $\mathrm{K}_{1}$ lineations of a $\mathrm{S}, \mathrm{SW}$, and $\mathrm{E}$ trend and moderate to shallow plunges. Three sites from Panna were sampled from the western and four along the southern part of the conduit, giving a similar pattern as seen at Baba; although the three sites are steeply plunging (Tab. 1). Grouping the sites from both Baba and Panna reveals a general distinction in the average trend of the $\mathrm{K}_{1}$ lineations; south-side sites are characterized by a mean trend of $181^{\circ}$ and plunge of $51^{\circ}$ and west-side sites trend $031^{\circ}$ and plunge $69^{\circ}$. The magnetic fabrics defined by the $\mathrm{K}_{1}-$ $\mathrm{K}_{2}$ plane all yield moderate (4 sites) to steeply ( 7 sites) dipping magnetic foliation planes of variable strike. For the majority of the sites from Baba and Panna, the means of the $K_{1}$ and $K_{2}$ axes do not overlap at $95 \%$ confidence and the sites are dominated by triaxial magnetic fabrics. We argue that the orientation of the $\mathrm{K}_{1}$ lineation reflects the magma flow direction during emplacement. The moderate to steep $\mathrm{K}_{1}$ lineations likely imply subvertical magma emplacement and the shallow $\mathrm{K}_{1}$ lineations are interpreted to indicate subhorizontal magma emplacement into the conduit. The orientation of the $\mathrm{K}_{1}$ axis from the conduits does not allow us to define a unique sense of flow (e.g., upward or downward; Knight and Walker 1988; Tauxe et al. 1998), but only a direction. During the growth of the Baba and Panna conduits, pulses of magma were likely injected into the shallow feeder system with magma flowing subvertically and at times laterally across the conduit.

\subsubsection{Dikes}

The majority of the dikes gave prolate ellipsoids along the margins. Only two dikes (Tr4c and Tr19b) yielded 


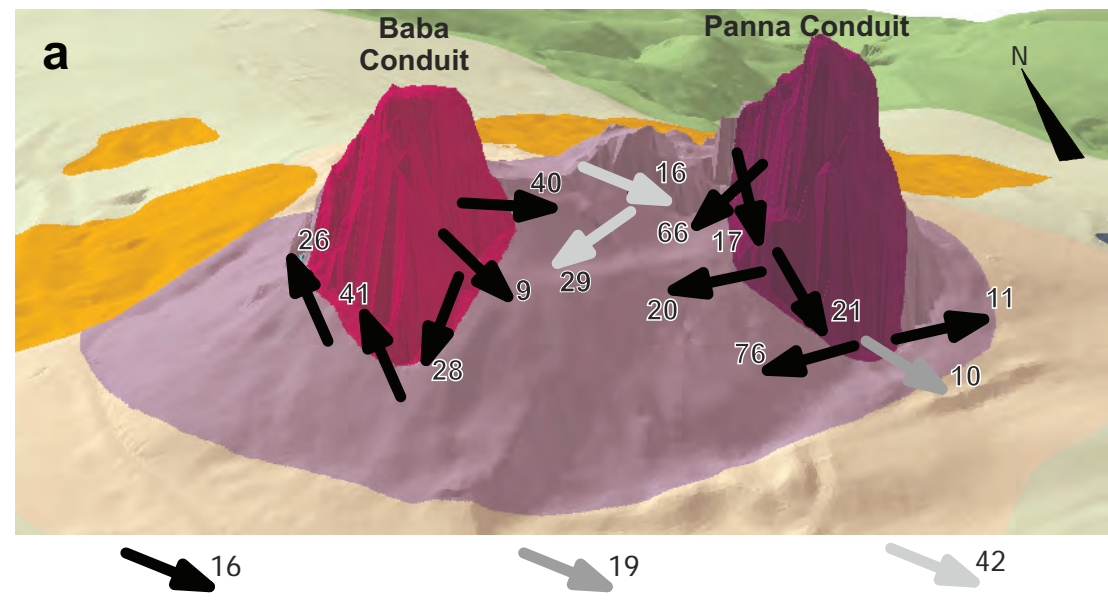

Conduit $\mathrm{K}_{1}$ flow direction

Dike paired margin flow direction

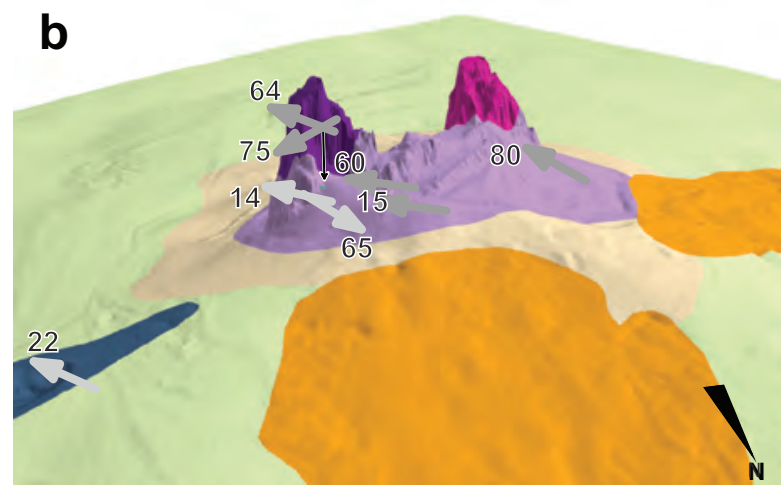

an oblate-shaped ellipsoid (Tab. 1). For the dikes dominated by the linear elements of the fabric, we estimate the magma flow pattern based on the methods outlined in Tauxe et al. (1998). When the planar elements prevail, we use the imbrication of the magnetic foliation plane from paired dike margins (Knight and Walker 1988; Fig. 1). The inferred magma flow paths for the sampled intrusion are shown in Fig. 11. In $\operatorname{Tr} 1$ the northeast, center, and southwest margins define an imbrication of the $\mathrm{K}_{1}$ axis, implying a downward flow to the southwest. In Tr2 the northeast, center, and southwest margins define an imbrication of the $\mathrm{K}_{1}$ axis and $\mathrm{K}_{1}-\mathrm{K}_{2}$ magnetic foliation plane that documents moderate plunging downward flow to the southeast. Both the southwest and northeast margins of dike $\operatorname{Tr} 4$ were sampled with the imbrication of the $\mathrm{K}_{1}$ lineations compatible with a downward inclined flow to the southeast. The southwest and northeast margins of dike $\operatorname{Tr} 11$ yield an imbrication of $\mathrm{K}_{1}$ lineation indicating a sub-horizontal magma flow to the E to NE. The southwest margin of Dike Tr19 yields an imbrication of the $\mathrm{K}_{1}-\mathrm{K}_{2}$ foliation plane that is nearly vertical and the imbrication of $\mathrm{K}_{1}$ lineation from the northeast margin are subvertical. Combined these data indicate magma flow that was subhorizontal towards the NE. The integrated results from the dikes that cut the Baba and Panna conduits and the
Baba plug

Panna plug

Scoria cone:

scoria, lavas, dikes

Basanite dike

Colluvial deposits

Landslides

Coniacian claystones and marlstones

Coniacian sandstones

Fig. 12 3D-sketch showing inferred magma flow directions based on the orientation of the $\mathrm{K}_{1}$ magnetic lineation axis or flow inferred from paired dike margins. Flow direction indicated by arrow, dip amount by attached number.

scoria portray subvertical flow into the Trosky volcano as well as subhorizontal flow away from the central feeder conduits (Fig. 12). Confronted with the paleomagnetic data, we infer a protracted period of magma emplacement with magma being fed both vertically, into the Trosky volcano, and subhorizontally, away from the conduits.

\subsection{Implications of the paleomagnetic data}

The rock magnetic data are interpreted to indicate that the paleomagnetic remanence directions are carried by a cubic, low- to medium-Ti titanomagnetite phase of a pseudosingle to multidomain grain size (Electronic Appendix 1). Most of the sites are characterized by a single component, stable end-point response which corresponds to distinct normal and reverse-polarity magnetizations. The presence of both normal and reverse polarity magnetization indicates that magmatism at the Trosky volcano spanned a polarity reversal. The results from Baba, Panna, lava flows, and one dike are statistically indistinguishable from the expected Miocene field direction $\left(\mathrm{D}=179.3^{\circ}, \mathrm{I}=-63.9^{\circ}, \alpha_{95}=5.2^{\circ}\right)$ but the results from four dikes are statistically distinct.

The dispersion of the Virtual Geomagnetic Poles (S) from Baba, Panna, and the lava flows are $\mathrm{S}=15.2,12.0$, 
and 4.5, respectively, which are low compared to the predicted dispersion estimate $\left(\mathrm{S}=17^{\circ}\right)$ for the $50^{\circ}$ latitude of the Trosky volcano. The low dispersion indicates that magma emplacement was rapid compared to the time scale of secular variation $\left(10^{2}-10^{3}\right.$ years $)$, which we interpret to indicate that Baba, Panna, and the lava flows were emplaced in a rapid succession during the Miocene.

Paleomagnetic data from the remaining four dikes yielded both normal (one site) and reverse (three sites) polarity site mean directions that are distinct from the expected Miocene field direction as well as the site mean data from Baba, Panna, and the lava flows. The likely interpretation is that these four dikes were injected later, following the construction of the main conduit and effusive eruptions. Compositionally the dikes are comparable to the other rocks constituting the Trosky volcano and likely represent a renewed episode of small-volume magmatism into the existing construct. The presence of a normal polarity dike and reverse polarity dikes that plot more than $45^{\circ}$ from the expected field direction cross cutting the conduits also implies a protracted period of magmatism. A reversal indicates a geomagnetic event resulting in an $180^{\circ}$ change in direction, accompanied by the restoration of the initial field intensity. When these two criteria are not met, then the term transitional field behavior is used. Excursions may be a special type of transitional field behavior and are defined as short-lived departures from a normal or reverse polarity field direction, where Virtual Geomagnetic Poles lie within $45^{\circ}$ of the expected pole (e.g., Verosub and Banerjee 1977). We argue that the data from the dikes are spot readings of the geomagnetic field and record high-amplitude secular variation (transitional

Fig. 13 Interpretive sketch of the growth of the Trosky volcano. a - Twin scoria cone with magma-feeding system including reservoir filling pseudokarst cavities, Strombolian-style eruptions associated with lava effusions; b - Deformation of cones and tilting of strata (including lavas) due to intrusions of highly crystallized (high effective viscosity) basanite pressed out by a new magma batch, formation of both volcanic spines within relatively short time-span; c - A late-stage injection of dikes into the construct; the paleomagnetic data constrain that this late magmatism occurred several thousand years (at least) after the initial growth of the Trosky volcano. field behavior) or an excursion at the time of emplacement.

\subsection{Growth of the Trosky volcano}

The Trosky volcano formed through a series of eruptions and magma emplacement events over an extended period of time. The development of this scoria cone began with a dike that propagated through the local bedrock. Once the dike reached the surface, it became a feeder conduit for the first scoria eruption(s) that produced Baba and associated effusive lava flows (Fig. 13a). We have documented significant compositional variability of lavas erupted on Trosky volcano contrasting to uniform composition of later plugs and dikes. The variability of lavas (olivine-rich, olivine-poor, clinopyroxene-rich and olivine-clinopyroxene equal types) suggests magma storage in a shallow magma chamber, where it could become zoned (olivine or clinopyroxene depleted/enriched zones). Setting of the lava in between both plugs suggests that Baba scoria cone was formed shortly before Panna cone. The volcanic strata comprising scoria beds and lavas were tilted (Fig. 4) steepening towards the plugs in main conduits. The tilting can be explained in terms of intrusion of plugs with increased viscosity, that were able to deform the scoria cones (Fig. 13b). Increased viscos-

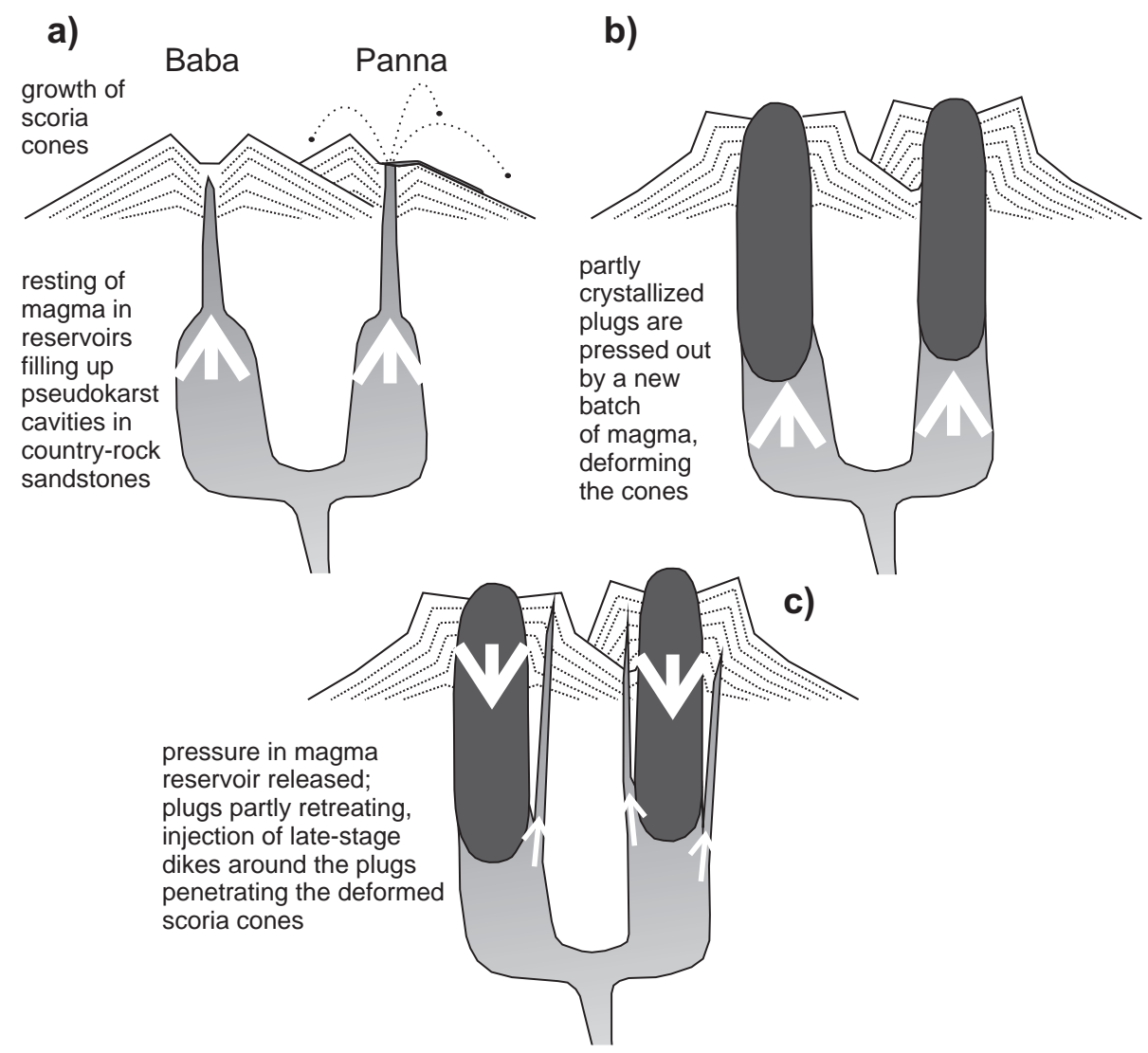


ity of basanite is in good agreement with high amount of quartz xenocrysts absorbed into the magma (Fig. 5e-f). The near-surface underground cavities associated with pseudo-karst (documented around Trosky: Mackovčin and Sedláček 2009) possibly formed already during Oligocene and Early Miocene, when the sandstone table rock was already modelled by erosion (Rapprich et al. 2007). These caverns could have provided opportunity for magma to rest and gain volume. In the pseudo-karst cavities the magma could have increased the effective viscosity by absorbing quartz grains from sandstones and cooling down. On the other hand, the paleomagnetic data for lavas suggest that the plugs were emplaced soon after formation of scoria cones, before the temperature of lavas dropped below the remanent magnetization temperature.

After the magma source was depleted, momentarily on the time scale of secular variation, the magma began to flow downward and laterally until equilibrium in pressure persisted long enough for the volcanic necks of Baba and Panna to become mostly solidified (Fig. 12). Following emplacement of Baba and Panna plugs, late dikes were injected into the construct. The paleomagnetic data constrain that this late stage of magmatism occurred several thousand years (at least) after the initial growth of the Trosky volcano (Fig. 13c). We argue that the Trosky volcano did not follow the classic monogenic evolution of scoria cone construction. It is becoming increasing clear (Foucher 2013; Petronis et al. 2013, 2014) that monogenic volcanic construction is often more complex than the simplistic models predict.

\section{Conclusions}

The results from the Trosky volcano based on field studies, petrology, AMS, and paleomagnetic data support the hypothesis that scoria cones often conceal multiple magma conduits and form over a protracted period of time; this notion deviates from classical growth models of monogenic volcanoes. Petrological data reveal significant compositional variability between the lavas erupted that contrasts with the uniform composition of the plugs and dikes. The variability of lavas indicates a shallow, zoned magma chamber that evolved during the growth of the volcano. The AMS data reveal magmatic flow directions that were variable with flow vertical (upward and downward) or subhorizontal (into and away from the volcano). Paleomagnetic data from the conduits and lava flows yield reverse polarity directions that are statistically indistinguishable from the expected mid-Miocene reverse polarity field direction. However, the dikes gave both normal and reverse polarity magnetizations. We argue that the growth of the Trosky volcano occurred over a protracted period of time and not due to simple "one shot" magmatic event, in contrast to long-standing monogenic growth models. The evolution and growth of some monogenic systems reflect interplay between local structures, magmatic effects, and construct evolution throughout the lifetime of the volcano.

Acknowledgements. This work represents a significant amount of data related to Mr. Adam Brister's master thesis at New Mexico Highlands University. Special thank you go to Dr. Tomáš Řídkošil, former director of the Český Ráj Geopark, for help with organizing of the field campaign and to the Český ráj (Bohemian Paradise) Protected Landscape Area Administration for permission to collect samples at the Trosky volcano. Dr. Tomáš Rídkošil passed away on July $2^{\text {nd }} 2015$ at the age of 62 . We dedicate this manuscript to his memory and all the hard work he has done over the many years promoting the Český Ráj Geopark and his efforts as a geologist at the Charles University in Prague, later in the Museum of Bohemian Paradise in Turnov and at the Secondary School of Applied Arts and the College of Craft Turnov. This work was funded by a National Geographic Grant (\#8887-11) awarded to Petronis and Lindline. The work of Rapprich was supported by the Czech Geological Survey. We also thank to reviewers Martin Chadima and Edgardo Cañon-Tapia, handling editor Jiří Žák and editor in chief Vojtěch Janoušek, as the manuscript significantly benefited from their comments and suggestions.

Electronic supplementary material. Rock magnetic data (and their discussion) as well as graphical presentation of the AMS data from individual sampling sites are available online at the Journal web site (http://dx.doi. org/10.3190/jgeosci.196). All raw specimen data from each site are available upon request from the authors.

\section{References}

Besse J, Courtillot V (2002) Apparent and true polar wander and the geometry of the geomagnetic field over the last 200 Myr. J Geophys Res: Solid Earth 107: 6-31

Birkenmajer K, Pécskay Z, Grabowski J, Lorenc M, ZAGOZDZON P (2004) Radiometric dating of the Tertiary volcanics in Lower Silesia, Poland. IV. Further K-Ar and paleomagnetic data from Late Oligocene to Early Miocene basanitic rocks of the Fore-Sudetic Block. Ann Soc Geol Pol 74: 1-19

Borradaile GJ, Henry B (1997) Tectonic applications of magnetic susceptibility and its anisotropy. Earth Sci Rev 42: 49-93

Bouchez JL (1997) Granite is never isotropic: an introduction to AMS studies of granitic rocks. In: BoucHEZ JL, Hutton DHW, Stephens WE (eds) Granite: From 
Segregation of Melt to Emplacement Fabrics. Kluwer, Dordrecht, pp 96-112

Bouchez J (2000) Magnetic susceptibility anisotropy and fabrics in granites. C R Acad Sci Paris 330: 1-14

CAJZ V (2000). Proposal of lithostratigraphy for the České středohoří Mts. volcanics. Věst Čes geol úst 75: 7-16

Cajz V, Rapprich V, Erban V, Pécskay Z, Radoñ M (2009) Late Miocene volcanic activity in the České středohoří Mountains (Ohře/Eger Graben, northern Bohemia). Geol Carpath 60: 519-533

Čech S, Adamová M, Baldík V, BŘízová E, Buda J, Burda J, ČÁp P, Drábková J, Dvořák I, Grygar R, Holásek O, Hradecká L, Hroch T, Janderková J, Kondrová L, Krumlová H, KrupičKa J, Mertlík J, Mlčoch B, Novotný R, Prouza V, Rapprich V, Rejchrt M, RÝda K, Řídkošil T, Skácelová Z, Smutek D, Svobodová M, ŠEBesta J, ŠimŮnek Z, ŠtafFen Z, Švábenická L, TASÁRYovÁ Z, UliČnÝ D, Zajíc J (2013) Explanation to the Basic Geological Map of the Czech Republic 1:25 000, sheet 03-342 Rovensko pod Troskami. Czech Geological Survey, Prague, pp 1-176

Coubal M, Adamovič J, Málek J, Prouza V (2014) Architecture of thrust faults with alongstrike variations in fault-plane dip: anatomy of the Lusatian Fault, Bohemian Massif. J Geosci 59: 183-208

Chapin C, Seager W (1975) Evolution of the Rio Grande Rift in the Socorro and Las Cruces Areas. In: SEAGER WR, Clemons RE, Callender JF (eds) Las Cruces Country. New Mexico Geological Society $26^{\text {th }}$ Annual Fall Field Conference Guidebook, New Mexico Geological Society Publications, Socorro, NM, pp 279-321

Dèzes P, Schmid SM, Ziegler PA (2004) Evolution of the European Cenozoic rift system: interaction of the Alpine and Pyrenean orogens with their foreland lithosphere. Tectonophysics 389: 1-33

Di Roberto A, Bertagnini A, Pompilio M, Bisson M (2014) Pyroclastic density currents at Stromboli volcano (Aeolian Islands, Italy): a case study of the 1930 eruption. Bull Volcanol 76: 827

DietL C (1999) Emplacement of the Joshua Flat-Beer Creek Pluton (White Inyo Mountains, California): a story of multiple material transfer processes. In: CASTRO A, Fernández C, Vigneresse JL (eds) Understanding Granites: Integrating New and Classical Techniques. Geological Society of London Special Publications 168: pp 161-176

ElLwood BB (1982) Estimates of flow direction for calcalkaline welded tuffs and paleomagnetic data reliability from anisotropy of magnetic susceptibility measurements: Central San Juan Mountains, southwest Colorado. Earth Planet Sci Lett 59: 303-314

Foucher M (2013) The Anatomy of a Cinder Cone: Paleomagnetic, Rock Magnetic, Structural, and Petrographic Data from the Cienega Volcano, Cerros del Rio Volcanic
Field, Northern New Mexico. Unpublished MSci. Thesis, New Mexico Highlands University, Las Vegas, pp 1-98

Geoffroy P, Olivier P, Rochette P (1997) Structure of a hypovolcanic acid complex inferred from magnetic susceptibility anisotropy measurements: the Western Red Hills granites (Skye, Scotland, Thulean Igneous Province). Bull Volcanol 59: 147-159

Hillhouse JW, Wells RE (1991) Magnetic fabric, flow directions, and source area of the Lower Miocene Peach Springs Tuff in Arizona, California, and Nevada. J Geophys Res 96: 12443-12460

Hintz A, Valentine G (2012) Complex plumbing of monogenetic scoria cones: new insights from the Lunar Crater Volcanic Field (Nevada, USA). J Volcanol Geotherm Res 239: 19-32

Holub FV, Rapprich V, Erban V, Pécskay Z, Mlčoch B, MíкоvÁ J (2010) Petrology and geochemistry of the Tertiary alkaline intrusive rocks at Doupov, Doupovské hory Volcanic Complex (NW Bohemian Massif). J Geosci 55: $251-278$

Horsman E, Tikoff B, Morgan S (2005) Emplacementrelated fabric and multiple sheets in the Maiden Creek sill, Henry Mountains, Utah, USA. J Struct Geol 27: $1426-1444$

Hrouda F (1982) Magnetic anisotropy of rocks and its applications in geology and geophysics. Geophys Surv 5: $38-82$

JELíNeK V (1978) Statistical processing of anisotropy of magnetic susceptibility measured on groups of specimens. Stud Geophys Geod 22: 50-62

JELÍNEK V (1981) Characterization of the magnetic fabric of rocks. Tectonophysics 79: 63-70

KING RF (1966) The magnetic fabric of some Irish granites. Geol J 5: 43-66

KirschVinK JL (1980) The least-square line and plane and the analysis of paleomagnetic data. Geophys J R Astron Soc 62: 699-718

KNIGHT MD, WaLKER GPL (1988) Magma flow directions in dikes of the Koolau Complex, Oahu, determined from magnetic fabric studies. J Geophys Res 93: 4301-4309

KNight MD, Walker GPL, Ellwood BB, Diehl JF (1986) Stratigraphy, paleomagnetism, and magnetic fabric of the Toba Tuffs: constraints on the sources and eruptive styles. J Geophys Res 91: 10355-10382

Kratinová Z, MacheK M, Kusbach V (2010) Fabric transpositions in granite plutons - an insight from non-scaled analogue modelling: J Geol Soc India 75: 267-277

Le Pennec Jl, Chen Y, Diot H, Froger JL, Gourgaud A (1998) Interpretation of anisotropy of magnetic susceptibility fabric of ignimbrites in terms of kinematic and sedimentological mechanisms: an Anatolian case-study. Earth Planet Sci Lett 157: 105-127

MackovČin P, Sedláček M (eds 2009) Protected Landscapes of Czech Republic, XIV. Nature Conservation Agency 
of the Czech Republic and Ekocentrum Brno, Prague, pp 1-608

O'Driscoll B, Troll VR, Reavy RJ, Turner P (2006) The Great Eucrite intrusion of Ardnamurchan, Scotland: reevaluating the ring-dyke concept. Geology 34: 189-192

ORT MH (1993) Eruptive processes and caldera formation in a nested downsag-collapse caldera: Cerro Pardzos, central Andes Mountains. J Volcanol Geotherm Res 56: 221-252

OwENs WH (1974) Mathematical model studies on factors affecting the magnetic anisotropy of deformed rocks. Tectonophysics 24: 115-131

OwENs WH (2000a) Statistical analysis of normalized and unnormalized second-rank tensor data, with application to measurements of anisotropy of magnetic susceptibility. Geophys Res Lett 27: 2985-2988

OwENs WH (2000b) Statistical applications to second-rank tensors in magnetic fabric analysis. Geophys J Int 142: $527-538$

OwENS WH, BAMFORD D (1976) Magnetic, seismic, and other anisotropic properties of rock fabrics. Philos Trans Roy Soc London 283: 55-68

Paterson SR, Fowler Jr TK, Schmidt KL, Yoshinobu AS, Yuan ES, Miller RB (1998) Interpreting magmatic fabric patterns in plutons. Lithos 44: 53-82

Pérez-López R, Legrand D, Garduño-Monroy VH, Rodríguez-Pascua MA, Giner-Robles JL (2011) Scaling laws of the size-distribution of monogenetic volcanoes within the Michoacán-Guanajuato Volcanic Field (Mexico). J Volcanol Geotherm Res 201: 65-72

Petronis MS, Hacker DB, Holm DK, Geissman JW, Harlan SS (2004) Magmatic flow paths and paleomagnetism of the Miocene Stoddard Mountain Laccolith, Iron Axis region, southwest Utah, USA. In: MARTíN-HERNÁNDEZ F, Lüneburg CM, Aubourg C. Jackson M (eds) Magnetic Fabric: Methods and Applications. Geological Society of London Special Publications 238: 251-283

Petronis MS, O'Driscoll B, Troll VR, Emeleus CH, Geissman JW (2009) Paleomagnetic and anisotropy of magnetic susceptibility data bearing on the emplacement of the Western Granite, Isle of Rum, NW Scotland. Geol Mag 146: 419-436

Petronis MS, Delcamp A, van Wyk de Vries B (2013) Magma emplacement into the Lemptégy scoria cone (Chaîne Des Puys, France) explored with anisotropy of magnetic susceptibility, and paleomagnetic data. Bull Volcanol 75: 753

Petronis MS, Rapprich V, Valenta J, Leman J, Brister AR, van Wyk de Vries B (2014) Emplacement of Zebín Hill, Jičín Volcanic Field, Bohemian Paradise, Czech Republic: anisotropy of magnetic susceptibility, ground magnetometry, and paleomagnetic data. AGU Fall 2014 Meeting Abstracts, San Francisco 1: 3563

RajChl M, UličnÝ D, GrYgar R, Mach K (2008) Evolution of basin architecture in an incipient continental rift: the
Cenozoic Most Basin, Eger Graben (Central Europe). Basin Res 21: 269-294

Rapprich V, Holub FV (2008) Geochemical variations within the Upper Oligocene-Lower Miocene lava succession of Úhošt' Hill (NE margin of Doupovské hory Mts., Czech Republic). Geol Q 52: 253-268

Rapprich V, Cajz V, KošŤák M, Pécskay Z, Řídkošil T, RAŠKA P, RADOŇ M (2007) Reconstruction of eroded monogenic Strombolian cones of Miocene age: a case study on character of volcanic activity of the Jičín Volcanic Field (NE Bohemia) and subsequent erosional rates estimation. J Geosci 52: 169-180

Rochette P (1987) Magnetic susceptibility of the rock matrix related to magnetic fabric studies. J Struct Geol 9: $1015-1020$

Rochette P, Jackson M, Aubourg C (1992) Rock magnetism and the interpretation of anisotropy of magnetic susceptibility. Rev Geophys 30: 209-226

Rosi M, Bertagnini A, Harris AJL, Pioli L, Pistolesi M, RIPEPE M (2006) A case history of paroxysmal explosion at Stromboli: timing and dynamics of the April 5, 2003 event. Earth Planet Sci Lett 243: 594-606

RoY JL, PARK JK (1974) The magnetization process of certain red beds: vector analysis of chemical and thermal results. Can J Earth Sci 2: 437-471

Sant'Ovaia H, Bouchez JL, Noronha F, Leblanc D, VignERESSE JL (2000) Composite-laccolith emplacement of the post-tectonic Vila Pouca de Aguiar granite pluton (northern Portugal): a combined AMS and gravity study. Trans Roy Soc Edinb, Earth Sci 91: 123-137

Seaman SJ, Mcintosh WC, Geissman JW, Williams ML, ELSTON WE (1991) Magnetic fabrics of the Bloodgood Canyon and Shelley Peak Tuffs, southwestern New Mexico: implications for emplacement and alternation processes. Bull Volcanol 53: 460-476

Sidman D, Ferre EC, Teyssier C, Jackson M (2005) Magnetic fabric and microstructure of a mylonite: example from the Bitterroot shear zone, western Montana. In: Bruhn D, Burlini L (eds) High-Strain Zones: Structure and Physical Properties. Geological Society of London Special Publications 245: 143-163

Stevenson CTE, Owens WH, Hutton DH, Hood DN, Meighan IG (2007) Laccolithic, as opposed to cauldron subsidence, emplacement of the Eastern Mourne Pluton, $\mathrm{N}$. Ireland: evidence from anisotropy of magnetic susceptibility. J Geol Soc, London 164: 99-110

TARLING DH, Hrouda F (1993) The Magnetic Anisotropy of Rocks. Chapman and Hall, London, pp 1-222

Tauxe L (1998) Paleomagnetic Principles and Practice, vol. 17 of Modern Approaches in Geophysics. Kluwer, Dordrecht, pp 1-316

Tauxe L, Gee JS, Staudigel H (1998) Flow direction from anisotropy of magnetic susceptibility data: the bootstrap way. J Geophys Res 103: 17775-17790 
ULIČNÝ D (2001) Depositional systems and sequence stratigraphy of coarse-grained deltas in a shallow-marine, strike-slip setting: the Bohemian Cretaceous Basin, Czech Republic. Sedimentology 48: 599-628

UličnÝ D, Laurin J, ČeCh S (2009) Controls on clastic sequence geometries in a shallow-marine, transtensional basin: the Bohemian Cretaceous Basin, Czech Republic. Sedimentology 56: 1077-1114

Ulrych J, Dostal J, Adamovič J, Jelínek E, Špaček P, HegNer E, BALogh K (2011) Recurrent Cenozoic volcanic activity in the Bohemian Massif(Czech Republic). Lithos 123: $133-144$

VanĚČKová M, Holub FV, Souček J, Bowes DR (1993) Geochemistry and petrogenesis of the Tertiary alkaline volcanic suite of the Labe Tectono-volcanic Zone, Czech Republic. Mineral Petrol 48: 17-34

Verosub KL, BanderJee SK (1977) Geomagnetic excursions and their paleomagnetic record, Rev Geophys 15: 145-155

Wood CA (1980) Morphometric evolution of cinder cones. J Volcanol Geotherm Res 7: 387-413
Ziegler PA, Dèzes P (2006) Crustal evolution of Western and Central Europe. In: Gee DG, Stephenson RA (eds) European Lithosphere Dynamics. Geological Society of London Memoirs 32: 43-56

ZIJDERVELD JDA (1967) A.C. demagnetization of rocks: analysis of results. In: COLLINSON DW, CREER KM, RuNCORN SK (eds) Methods in Paleomagnetism. Elsevier, Amsterdam, pp 254-286

Ž́́́ J, Holub FV, Verner K (2005) Tectonic evolution of a continental magmatic arc from transpression in the upper crust to exhumation of mid-crustal orogenic root recorded by episodically emplaced plutons: the Central Bohemian Plutonic Complex (Bohemian Massif). Int J Earth Sci 94: 385-400

Žák J, Kratinová Z, Trubač J, Janoušek V, Sláma J, MrLina J (2011) Structure, emplacement, and tectonic setting of Late Devonian granitoid plutons in the Teplá-Barrandian Unit, Bohemian Massif. Int J Earth Sci 100: 1477-1495

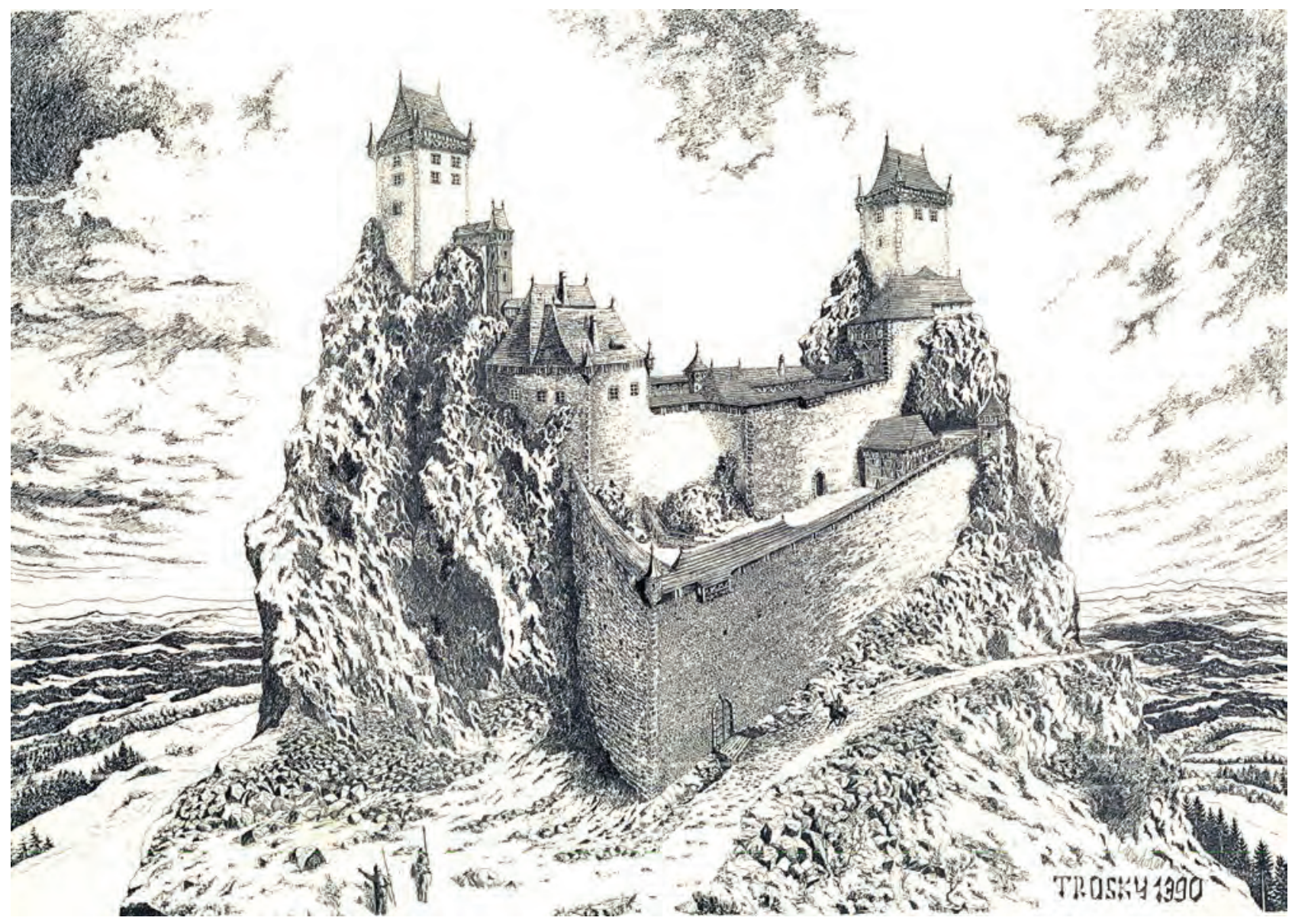

Reconstruction of the Trosky castle by Ladislav Tomás - situation in 1390 